\title{
Hormonal and Neural Mechanisms Regulating Hormone Steroids Secretion
}

\author{
Roberto Domínguez ${ }^{1}$, Angélica Flores ${ }^{1}$ and Sara E. Cruz-Morales ${ }^{2}$ \\ ${ }^{1}$ Facultad de Estudios Superiores Zaragoza, \\ ${ }^{2}$ Facultad de Estudios Superiores Iztacala \\ Universidad Nacional Autónoma de México \\ México
}

\section{Introduction}

Hormonal and neural signals participate in regulating the synthesis and release of steroid hormones from the adrenals, ovaries and testicles. Hormonal signals arise from the hypothalamus, pituitary, thyroid, thymus, adipose tissue, as well as from the adrenals, ovaries and testicles. Neural signals originating in the hypothalamus and other regions of the central and peripheral nervous system modulate the responses to the hormonal signals sent to the adrenals, ovaries and testicles.

In female, the involvement of the adrenal and ovarian innervations in regulating the synthesis and release of steroid hormones have shown that right and left organs have different abilities to carry out these functions (Gerendai et al., 2000; Domínguez et al., 2003). The asymmetric capacity to release steroid hormones is related to differences in the origin and type of innervations received by right and left organs (Tóth et al., 2007; Gerendai et al., 2009). In addition, the way neuroendocrine signals participate in regulating steroid hormones secretion is different for each hormone, and the release of ovarian hormones is regulated according to the day of the estrus cycle.

Scientific reviews on the biochemical steps that take place during the capture and processing of cholesterol and synthesis of steroid hormones, as well as in the regulation of the enzymes activities have been published in the last decade (Auchus \& Miller, 2000; Straus \& Hsue, 2000; Stocco, 2008; Boon et al., 2010; Chung et al., 2011). In such regard, the present chapter presents only a summary of those aspects we think are relevant to analyze the neuroendocrine regulation of steroid hormones secretion.

\section{Steroid hormones}

Steroid hormones are classified according to the number of carbon (C) atoms in the molecule deriving from the pregnane (C-21), androstane (C-19) or estrane (C-18) nucleus. C-21 hormones include progesterone, cortisol, corticosterone and aldosterone; $\mathrm{C}-19$ testosterone, androstenedione (A4) and dihydrotestosterone; and C-18 estradiol, estrone and estriol. Based on its functional actions, steroid hormones are classified into five principal classes: estrogens (estradiol, estrone, estriol), progestins (progesterone), androgens (testosterone, A4, 
dihydrotestosterone), glucocorticoid (cortisol, corticosterone), and mineralocorticoids (aldosterone, deoxicorticosterone).

All steroid hormones derive from cholesterol in a process that includes:

- de novo synthesis of cholesterol from acetate, the cholesterol release from cholesterol esters stored in lipid cytoplasmic droplets, and the capture and processing of blood cholesterol

- $\quad$ the transport of cholesterol to the mitochondria;

- the conversion of cholesterol to pregnenolone;

- $\quad$ the transport of pregnenolone to the smooth endoplasmic reticulum;

- modifications of the pregnenolone molecule and the synthesis of active hormones;

- the transport of active hormones to the cell membrane and the release of hormones to the blood stream;

- the biosynthesis of new hormones in the peripheral tissues through enzymes acting on steroid hormones as precursors;

- the activation or inactivation of steroid hormones by organs or tissues; the catabolism and elimination of catabolites by urine, bilis or feces;

- the esterification of the steroid hormone molecules and its elimination through the urine, bilis or feces.

\section{Capture and processing of cholesterol}

Cells synthesizing steroid hormones (steroidogenic cells) use several pathways that ensure the constant supply of cholesterol for steroid hormone synthesis, including:

1. De novo synthesis from acetate in the endoplasmic reticulum;

2. The mobilization of cholesterol esters stored in lipid droplets through cholesterol-ester hydrolase;

3. The uptake of blood lipoproteins carrying cholesterol (low-density (LDL) and highdensity lipoproteins (HDL).

The incorporation of lipoproteins into the cells is mediated by a receptor-endocytic mechanism that delivers the lipoproteins to the lysosomes where apolipoproteins are degraded. High density lipoproteins (HDL) are incorporated by the scavenger receptor class B, type I (SR-BI)-mediated selective uptake. Depending on the cell, the synthesis of lipoprotein receptors is stimulated by the adreno-corticotropin-hormone (ACTH) and luteinizing hormone (LH). The source of cholesterol for steroidogenesis varies according to the animal studied (Azhar et al., 2003; Hu et al., 2011). SR-BI synthesis in adrenal cells is stimulated by ACTH and inhibited by glucocorticoids (Mavridou et al., 2010).

The membrane-bound transcription factor sterol regulatory element binding protein (SREBP) is the main regulator for cholesterol synthesis and cellular uptake. In mammalian cells, protein Insig, an endoplasmic- reticulum membrane protein, controls the activity of SREBP and the sterol-dependent degradation of the biosynthetic enzyme HMG-CoA reductase (Espenshade \& Hughes 2007).

The cholesterol side chain cleavage reaction is the first step, and also the rate-limiting process in steroid hormone synthesis. The reaction takes place on the inner mitochondrial membranes and is catalyzed by the cholesterol-side-chain cleavage enzyme, cytochrome P450scc; Cyp11a1 (Straus \& Hsue, 2000). The translocator protein (TSPO) and the steroidogenic acute regulatory (StAR) protein mediate this transfer. TSPO is a high-affinity cholesterol-binding mitochondrial protein and StAR is a hormone-induced mitochondria protein that initiates the transfer of cholesterol into the mitochondria (Hu et al., 2010). In 
vitro studies show that treating Leydig cells with testosterone decreases the expression of SR-BI, TSPO, StAR and cytochrome P-450scc (Kostic et al., 2011). In the adrenals, ACTH induces StAR synthesis by stimulating the synthesis of cyclic adenosin mono phosphate (cAMP), while the early steps in steroidogenic synthesis are mediated by posttranscriptional and post-translational changes in the StAR protein (Spiga et al., 2011). In the gonads, gonadotropic hormones transcriptionally control StAR gene expression via a cAMP second messenger (Sugawara et al., 1997). A characteristic feature of steroidogenic cells is the presence of numerous cytoplasmic lipid droplets containing cholesterol esters. Cholesterol esters in these droplets are synthesized by acyl coenzymeA-cholesterol acyltransferase, an endoplasmic reticulum-enzyme. The esters synthesized by cholesterol acyltransferase accumulate within the endoplasmic reticulum membranes and bud off as lipid droplets. Cholesterol esters in lipid droplets are hydrolyzed by a soluble sterol ester hydrolase. Gonadotropins stimulate the activation of cAMP-dependent-protein kinase that activates this enzyme by phosphorylating specific serine residues, thus promoting binding of the sterol esterase to lipid droplets and the hydrolysis of cholesterol esters.

Cholesterol is converted into pregnenolone, and the rate of pregnenolone synthesis is determined by:

1. The rate of cholesterol delivery to the mitochondria;

2. The access of the inner mitochondrial membranes to cholesterol;

3. The available quantity of cholesterol side chain cleavage enzyme and, secondarily its flavoprotein and iron sulfur protein electron transport chain;

4. The catalytic activity of P-450scc.

Acute alterations in steroidogenesis generally result from changes in the delivery of cholesterol to P-450scc, whereas long-term alterations involve changes in the quantity of enzyme proteins, as well as cholesterol delivery (Straus \& Hsue, 2000).

\section{Enzymes participating in the synthesis of steroid hormones}

The synthesis of the numerous enzymes participating in steroid hormones synthesis is under the stimulatory effects of hormones secreted by the pituitary ACTH, LH and follicle stimulating hormone (FSH). Other pituitary hormones, such as growth hormone (GH) and prolactin (PRL), also play a role regulating the synthesis of some of these enzymes.

Based on the progression of changes occurring to the cholesterol molecule, four enzymes seem to be crucial for hormone synthesis: cytochrome P-450scc, 3 $\beta$-hydroxysteroid dehydrogenase $/ \Delta 5$-4-isomerases (3 $\beta$-HSDs), 17 a-Hydroxylase/17,2O-desmolase, and aromatase cytochrome $\mathrm{P} 450$

\subsection{Cytochrome P-450scc}

The cytochrome P-450scc side chain cleavage is an enzyme present in the inner mitochondrial membranes. The enzyme is involved in three catalytic cycles on the cholesterol molecule: the introduction of hydroxyl groups at positions C-22 and C-20, and the subsequent scission of the side chain between these carbons. ACTH and LH stimulate cytochrome P-450scc synthesis in a mechanism that depends on cAMP synthesis as a second messenger (Auchus \& Miller, 2000; Straus \& Hsue, 2000).

\section{2 $3 \beta$-Hydroxysteroid dehydrogenase $/ \Delta 5$-4-isomerases}

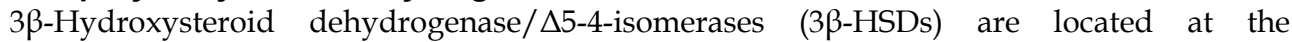
microsomal fraction, and are expressed in the adrenal cortex and in steroidogenic cells of the 
gonads. The expression of $3 \beta-H S D$ s is enhanced by ACTH and LH. These isomerases catalyze the formation of $\Delta 4-3$-ketosteroids from A5-3 $\beta$-hydroxysteroids, an obligate step in the biosynthesis of progestins, androgens, estrogens, mineralocorticoids and glucocorticoids. $3 \beta$-HSDs catalyze the dehydrogenation of the 3B-equatorial hydroxyl group and the subsequent isomerization of the olefinic bond to yield the $\mathrm{A}_{4}$ 3-ketone structure; converting pregnenolone into progesterone, 17a-hydroxypregnenolone into 17ahydroxyprogesterone, and dehydroepiandrosterone into A4.

Protein kinase A signaling activators (forskolin, dibutyrylcAMP) increase the synthesis of dehydroepiandrosterone and A4, as well as the levels of $3 \beta-H S D$ and P-450c17 mRNA transcripts. Activation of the protein kinase $C$ pathway by phorbol ester treatment also elevates 3 $\beta$-HSD mRNA levels and lowers P-450cl17 mRNA levels (Auchus \& Miller. 2000).

\section{$4.317 \alpha$-Hydroxylase/17,20-Desmolase}

The $17 \alpha$-Hydroxylase/17,2O-Desmolase (P-45Oc7f or CYP17A1 ITl) is a cytochrome P450 enzyme with $17 \alpha$-hydroxylase and 17,20-lyase activities that catalyzes two reactions: the hydroxylation of pregnenolone and progesterone at carbon 17, and the conversion of pregnenolone into C-19 steroids. P-450c17 is a key enzyme in the steroidogenic pathway producing all steroid hormones (progestins, mineralocorticoids, glucocorticoids, androgens, and estrogens). The theca cells of the follicle and the theca lutein cells of the corpus luteum, as well as the ovarian stroma, the adrenal gland, and Leydig cells express P-450c17. (Auchus \& Miller, 2000; Straus \& Hsue, 2000).

\subsection{Aromatase cytochrome P-450c17}

Aromatase cytochrome P-450 c17 is an enzyme found in the endoplasmic reticulum membrane that acts on aromatizable androgen. Aromatase P 450 catalyses the biosynthesis of all estrogens from androgens by transforming the A-ring of steroids to an aromatic state through the oxidation and elimination of the C19 methyl group (Ghosh et al., 2009; Straus \& Hsueh, 2000). Aromatase expression is present in fetal and immature ovaries, and in rodents, aromatase expression/activity is restricted to the gonads and the brain. In humans, aromatase activity is expressed by the adrenal medulla (Belgorosky et al., 2008), adipose tissue, breast, skin, and bone (Czajka-Oraniec \& Simpson, 2010).

FSH is the main factor inducing aromatase activity in mural granulosa cells located on the outer edge of healthy large antral follicles and luteal cells. Aromatase is not expressed in cumulus granulosa cells. The stimulatory effects of FSH are modulated in an inhibitory way by glucocorticoids, prolactin, progestins, inhibin, triiodothyronine and thyroxine (T3-T4) (Chen et al., 2010). Transforming growth factor- $\beta$ (TGF- $\beta$ ) enhances FSH effects (Stocco, 2008).

Bone morphogenetic protein 15 (BMP-15) and growth differentiating factor 9 (GDF9) produced by the oocytes also stimulate aromatase expression and the stimulatory effects of the tumor necrosis factor- $\alpha$ (TNF- $\alpha$ ), epidermal growth factor (EGF), transferrin, nitric oxide (NO), and superoxide dismutase (Stocco 2008). Leptin has stimulatory or inhibitory effects on aromatase expression depending on the animal studied (Sirotkin \& Grossman, 2007).

Acting as an autocrine signal, estradiol enhances the stimulatory effects of FSH on aromatase activity in granulosa cells, and its effects are mediated by the activation of estrogen receptor $\beta$ (Wang et al., 2010).

Androgens enhance FSH effects on aromatase expression by increasing cAMP levels. Aromatizable androgens synthesized by theca-internal cells are the substrate for estrogen 
synthesis. The stimulating actions of FSH on aromatase are potentiated by insulin-like growth factor-1 (IGF-1), because IGF-I stimulates the capacity of granulosa cells to respond to FSH (Stocco 2008).

FSH stimulates the synthesis of cAMP, which in turn acts as an intracellular messenger mediating FSH stimulation of aromatase expression, leading to the activation of the cAMPdependent protein kinase A (PKA) which is cAMP-dependent (Stocco, 2008). FSH stimulates the mRNA for $\mathrm{LH}$ receptor synthesis, explaining why $\mathrm{LH}$ is the main aromatase inductor before ovulation (Boon et al., 2010).

\section{Hormonal signals}

The regulation of steroid hormones synthesis is mediated by hormones secreted by the pituitary, thyroid, adipose tissue, neuropeptides, adrenals, ovaries and testicles.

\subsection{Pituitary hormones}

The pituitary secretes several hormones that stimulate the release of steroid hormones. In this process, two key hormones are the ACTH and $\mathrm{LH}$, and their release is pulsating. Higher cortisol, progesterone, testosterone, and estradiol levels in serum are observed minutes after each ACTH or LH pulse. By acting on the expression of several genes, ACTH and LH stimulate the synthesis of enzymes participating in the conversion of cholesterol to steroid hormones, a process that can take hours or even days. The rapid increase in steroid hormone concentrations after the injection of ACTH or LH cannot be explained by the synthesis of enzymes participating in steroid hormones synthesis and release. Based on several studies, it has been proposed that the rapid increase in steroid hormones levels is mediated by a c-AMP action resulting in StAR synthesis, one of the proteins carrying the cholesterol to the mitochondria, the first step in steroid hormones synthesis (Auchus \& Miller, 2000).

The first step in the acute response to hormonal stimulation for steroid biosynthesis is the delivery of cholesterol from the outer to the inner mitochondrial membrane; a process that depends on de novo StAR protein synthesis and phosphorylation. LH and ACTH stimulate the synthesis of StAR by increasing cAMP levels and its phosphorylation rate (Luo et al., 2010).

LH plays a dual role in regulating P-450 enzymes participating in the synthesis of steroid hormones. Following the initial stimulation synthesis of the enzyme, LH exerts a down regulation on the synthesis of granulosa-specific CYP19A1 and theca-specific CYP17A1 transcripts and lowers the abundance of HSD3B1 transcripts (Nimz et al., 2010).

In female rabbits, hyperprolactinemia inhibits the peripheral and ovarian venous progesterone and 20 alpha-hydroxypregn-4-en-3-one (20 alpha-OHP) levels increase stimulated by human chorionic gonadotropin (hCG), without causing changes in the estradiol, androstenedione and testosterone levels (Lin et al., 1987).

\subsection{Adipose tissue hormones}

The adipose tissue secretes several adipose-derived polypeptidic hormones. Together, adipose-derived polypeptidic hormones receive the name of adipokines. Adipokines act locally and distally through autocrine, paracrine and endocrine effects (Ronti et al., 2006), and participate in the regulation of appetite and metabolic processes. Experimental studies show that some adipokines play a role regulating steroid hormones secretion by different organs. 


\subsubsection{Leptin}

Leptin is a hormone secreted by the adipose tissue, and its participation in the regulation of steroid hormones is controversial. In vitro studies show that the participation of leptin in the regulation of steroid hormones release depends on the species studied. In avian ovarian cells leptin stimulates the release of progesterone and estradiol, blocks testosterone secretion, and does not affect arginine-vasotocin secretion (Sirotkin \& Grossmann 2007). In granulosa cells from rats, high leptin concentrations inhibits the stimulatory effects of insulin-like growth factor I (IGF-I) on FSH-stimulated estradiol secretion, but does not affect progesterone secretion (Zachow and Magoffin, 1997; Duggal et al., 2002; Ricci et al., 2006). In cultured granulosa cells leptin also suppresses the stimulating effect of the transforming growth factor $\beta$ (TGF- $\beta$ ) on FSH-dependent estrone and estradiol secretion, as well as in aromatase mRNA expression and aromatase activity (Zachow et al., 1999).

Leptin inhibits insulin-induced estradiol secretion by granulosa cells and decreases the insulin-induced increases of progesterone production in bovine granulosa cells (Spicer \& Francisco, 1997). Co-stimulated by FSH and dexamethasone, leptin blocks steroid hormone synthesis by the ovaries and the synthesis of pregnenolone, progesterone, and 20alphahydroxy-4-pregnen-3-one. Leptin also reduces the expression of adrenodoxin, an enzyme in the P50scc electron transport system (Barkan et al., 1999), and inhibits the synthesis of insulin-stimulated progesterone production from human luteinized granulosa cells (Brannian et al., 1999). The synthesis of functional leptin receptors depends on pituitary hormones, since hypophysectomized rat theca cells do not have such receptors (Zachow et al., 1999).

Studies in human granulosa cells suggest that in vitro the effects of leptin on the secretion of estradiol and progesterone depend on the doses used; with low doses of leptin having a stimulatory effect and high doses an inhibitory effect (Karamouti et al., 2009). Leptin and leptin fragments enhance the secretory activity of aldosterone and corticosterone by the adrenal cortex of rats (Malendowicz et al., 2003; Markowska et al., 2004). However, later studies by Malendowicz et al., (2007) reported that leptin inhibits steroid-hormone secretion from the adrenal cortex by lowering the response to stress of the hypothalamic-pituitaryadrenal (HPA) axis and by increasing the release of catecholamines from the adrenal medulla. Because leptin Ob-receptor is expressed in the adrenal gland, it seems that leptin modulates adrenal hormones secretion by acting as a circulating hormone (Malendowicz et al., 2007). Leptin blocks the ovarian steroid synthesis co-stimulated by FSH and dexamethasone. In vitro studies show that leptin inhibited the secretion of pregnenolone, progesterone, and 20alpha-hydroxy-4-pregnen-3-one, as well as the secretion of progesterone induced by the co-stimulation by forskolin and dexametasene; without modifying the forskolin induction of cAMP (Barkan et al., 1999).

\subsubsection{Adiponectin}

Adiponectin is an adipocyte hormone participating in lipid metabolism and glucose homeostasis. Adiponectine receptors and its mRNA are expressed in the ovaries and testicles. Pituitary gonadotropins have low effects on adiponectin mRNA testicular levels. Metabolic signals, such as glucocorticoids, thyroxine, and peroxisome proliferator-activated receptor-gamma modulate the expression of adiponectin mRNA. In vitro studies show that 
recombinant adiponectin inhibits basal and human chorio-gonadotropin-stimulated testosterone secretion by adult rat testicles (Caminos et al., 2008).

\subsection{Gut hormones}

The gut secretes several polypeptidic hormones that participate in regulating the brain-gut relationship with different organs in the digestive system. Experimental studies show that some gut hormones also play a role regulating the secretion of steroid hormone.

\subsubsection{Secretin and gastric inhibitory polypeptide}

Secretin and gastric inhibitory polypeptide (GIP), together with glucagon, parathyroid hormone (PTH), vasoactive intestinal peptide (VIP) and pituitary adenylate cyclaseactivating polypeptide, belong to the VIP-secretin-glucagon super family.

Secreted by the duodenum, secretin is a hormone that selectively depresses the glucocorticoid response to ACTH of dispersed zona fasciculata-reticularis cells. By inhibiting the cascade of $\mathrm{AC} /$ protein kinase $\mathrm{A}$, glucagon, and glucagon-like peptide-1 secretin depresses the response of cells in the zona fasciculata-reticularis to ACTH. PTH and PTH-related protein stimulate aldosterone and glucocorticoid secretion of dispersed zone glomerulosa and zone fasciculata-reticularis cells (Nussdorfer, 2000).

The intra-peritoneal injection of GIP increases corticosterone plasma concentrations in a dose-dependent manner, without affecting aldosterone levels. GIP did not affect aldosterone and cyclic-AMP release by dispersed zone glomerulosa cells, but increased basal corticosterone secretion and cyclic-AMP release by dispersed inner adrenocortical cells. In rats, GIP stimulates the basal secretion of glucocorticoids by acting through specific receptors coupled with the adenylatecyclase/PKA-dependent signaling pathway (Mazzocchi et al 1999).

\subsubsection{Obestatin}

Produced in the stomach and other tissues, obestatin is one of the metabolic hormones that has effects on systems other than the digestive system. In in vitro porcine granulosa cells, obestatin increases the secretion of progesterone, without modifying testosterone or estradiol secretion (Mészárosová et al., 2008). Thus, it is possible that obestatin stimulates StAR phosphorylation without affecting the activity of the enzymes participating in androgen synthesis.

\subsection{Neuropeptides}

The term neuropeptide refers to polypeptidic molecules synthesized and released by neurons that can act neurotransmitters and/or hormones. Common neuropeptides include orexins (A \& B) and galanin.

\subsubsection{Orexins}

Orexin-A and orexin-B (hypocretin-1 and -2) are two neuropeptides produced by neurones located in the lateral hypothalamus. Orexins A and B bind to two different receptors that are coupled to $G$ proteins. Both neuropeptides raise basal corticosterone secretion by dispersed cells obtained from the rat's fasciculate-reticular zone, and do not affect either maximally 
ACTH stimulated corticosterone production by cells of the fasciculate-reticular zone or the basal and agonist-stimulated aldosterone secretion of dispersed cells from the glomerulosa zone. The ACTH-receptor antagonist corticotropin-inhibiting peptide blocks the secretion of corticosterone induced by ACTH to cells from the fasciculate-reticular zone, but does not modify orexins effects. Both orexins enhance cyclic-AMP release by cells in the fasciculatereticular zone. The selective inhibitor capacity of protein-kinase A (PKA) H-89 decreased corticosterone responses to both ACTH and orexins. A subcutaneous injection of orexin A and $\mathrm{B}$ evokes a clear-cut increase in the plasma concentration of corticosterone, but not of aldosterone. The effect of orexin-A on corticosterone release is higher than the effect of orexin-B. Based on these results the authors suggest that orexins exert a selective and direct glucocorticoid secretagogue action on the adrenals of the rat, acting through a receptormediated activation of the adenylate cyclase/PKA-dependent signaling pathway (Malendowicz et al., 1999).

Stimulating orexin receptors results in higher ACTH secretion by the pituitary and has a direct stimulatory effect on adrenocortical cells (Malendowicz et al., 1999; Spinazzi et al., 2006; Kagerer \& Jöhren 2010).

\subsubsection{Galanin}

Galanin is a 29- or 30- amino acid long neuropeptide expressed in the brain, spinal cord, and gut that acts via three subtypes of $G$ protein-coupled receptors. Galanin increases the basal secretion of cortisol from dispersed inner adrenocortical cells, without affecting the effects of ACTH (Belloni et al., 2007). Galanin stimulates the release of corticotrophin releasing hormone (CRH) and $\mathrm{ACTH}$, enhances glucocorticoid secretion by the adrenal cortex, and directly stimulates corticosterone secretion from the adrenals through GAL-R1 and GAL-R2 receptors and the release of noradrenaline from the adrenal medulla. Other results suggest that galanin increases corticosterone release via an indirect paracrine mechanism involving the local release of catecholamines, which in turn activates beta-adrenoceptors located on adrenocortical cells (Tortorella et al., 2007).

\subsubsection{Vasoactive intestinal peptide and neuropeptide $Y$}

The VIP and neuropeptide Y (NPY) are the most abundant transmitter-peptides in the adrenal gland (Whitworth et al., 2003). These peptides act as neurotransmitters and exert endocrine, paracrine or autocrine effects in numerous cell types, particularly in the adrenals and ovaries. In vitro, the adrenal responsiveness to VIP depends on the model used: in rats, VIP stimulates aldosterone production by the adrenal capsular tissue (Cunningham \& Holzwarth, 1988) and by intact perfused adrenal glands (Hinson et al., 1992), but not by dispersed zona glomerulosa cells (Enyedi et al., 1983; Hinson et al., 1992). There is evidence that VIP acts on chromaffin cells present beneath the adrenal capsule, stimulating the release of catecholamines, which in turn stimulate aldosterone secretion (Whitworth et al., 2003). It seems that the mechanisms used by NPY in the adrenals are the same as those used by VIP (Renshaw et al., 2000).

\subsubsection{Pituitary Adenylate Cyclase-Activating Polypeptide (PACAP)}

The pituitary adenylate-cyclase activating polypeptide (PACAP) and its receptors are present in the central nervous system (CNS), the testicles, adrenals, and ovaries. LH increases PACAP mRNA levels in pre-ovulatory follicles, and stimulates estrogen and 
progesterone secretion by granulosa cells stimulated with hCG (Lee et al. 1999). In the adrenals, PACAP stimulates VIP synthesis, which in turn stimulates hormones release (AitAli et al., 2010).

\subsection{Adrenal hormones}

The adrenals secrete steroid hormones, catecholamines and peptidergic hormones. Evidence suggests that almost all the adrenal hormones play a role on their own regulatory process.

\subsubsection{Endothelins}

Endothelins (ETs) are a family of vasoactive peptides secreted by vascular endothelium. ETs play autocrine/paracrine regulatory functions, acting via two subtypes of receptors, ET-A and ET-B. The endocrine cells in the glomerulosa cells of the adrenal cortex express both ETA and ET-B. The cells of the zone fasciculata/reticularis mainly express ET-B. ETs stimulate the secretion of mineralocorticoids by glomerulosa cells. Its effects on glucocorticoid secretion are lower (Nussdorfer et al., 1997). The effects of ETs on steroidogenic cells are mediated through the activation of various signaling mechanisms, including the stimulation of phospholipase C, phospholipase A2 and adenyl cyclase activity, as well as calcium influx through plasma channels (Delarue et al., 2004).

\subsubsection{Noradrenaline}

Noradrenaline (NA) is a cathecolamine secreted by neurons in the adrenal medulla and by chromaffin cells present in the adrenal cortex. In luteal bovine cells NA stimulates progesterone secretion through the beta 1- and beta 2-adrenoceptors. NA also increases cytochrome P-450scc and 3 beta-HSD activity. Prostaglandin F (PGF) inhibits the luteotropic effect of NA on the luteal tissue (Miszkiel\&, Kotwica, 2001).

\subsubsection{Dopamine}

Human granulosa cells (GCs) express 4 out of 5 dopamine (DA) receptors (D1 and D5 coupled and linked to cAMP increase, D2 and D4; Gi/Gq coupled and linked to IP3/DAG. In vitro, the stimulation of human granulosa cells with hCG did not increase mRNA or protein levels of DA receptors. D1 and D2 receptors are also present in the ovaries of rats (Rey-Ares et al., 2007).

\subsection{Thyroid hormones}

The thyroid mainly secretes triyodo tyrosine (T3), tiroxine (T4) and calcitonin. T3 and T4 play several roles in regulating all the mammalian organs and systems.

Rats with hypothyroidism present high progesterone and low testosterone levels, without apparent changes in basal estradiol levels (Hatsuta et al., 2004). Acute experiments with murine Leydig cells, T3 induced StAR expression and progesterone production (Manna et al., 1999). In contrast, chronically stimulating mice Leydig tumor cells with T3 inhibits StAR expression and progesterone production, mainly by decreasing the delivery of cholesterol to the inner mitochondrial membrane (Manna et al., 2001). In cultivated Leydig cells, T3 treatment increased testosterone and estradiol secretions in a dose dependent manner (Maran et al., 2000). 


\subsection{Protein kinases and cAMP}

Protein kinases (PKs) are a group of enzymes that modify other enzymes by adding phosphate groups (phosphorylation), which changes the enzyme's activity.

PKs participate in regulating the release of steroid hormones. Ovarian cells produce a number of PKs whose expression depends on the type of cell, their state and the action of hormones and other PKs (Sirotkin et al., 2011). In mammalian ovarian cells, PK-A stimulates the release of progesterone and estradiol (Makarevich et al., 2004); while others affirm that PKA inhibits progesterone, testosterone and estradiol release by mammalian ovarian follicular cells (Dupont et al., 2008). In chickens, PK-A either stimulates or suppresses the release of progesterone, testosterone and estradiol (Sirotkin \& Grossmann, 2006, 2007b). In corpus luteum, PK-A promotes the release of progesterone by large luteal cells, while PK-C inhibits the release of progesterone and maintains luteal prostaglandin 2 alpha release (Diaz et al., 2002; Niswender, 2002). According to Makarevich (2004) PK-A type II is more important for the control of ovarian steroidogenesis than PK-A type I.

Rabbit ovaries treated in vitro with dbcAMP secrete less progesterone and testosterone, but basal estradiol release remained unchanged. Adding FSH, IGF-I, and ghrelin reduced progesterone release, and adding only ghrelin increased the release of testosterone without modifying estradiol output. Previous treatment with dbcAMP inverted the inhibitory to stimulatory action of FSH, IGF-I and ghrelin on progesterone release (Chrenek et al., 2010).

\subsection{Ovarian signals}

Like the adrenal glands, the ovaries secrete steroid and polypeptidic hormones that regulate /modulate the synthesis and release of ovarian hormones.

Estradiol regulates the synthesis of androgens by the follicular theca interna in an inhibitory way. Estrogens and androgens inhibit progesterone secretion by the human corpus luteum. The effects of testosterone and androstenedione are mediated by their conversion to estrogens (Tropea et al., 2010). Androgens stimulate cytochrome P450 aromatase mRNA concentrations in granulosa cells. The effects depend on the androgen studied, suggesting that the expression of the aromatase gene has differential regulation in the developing follicle (Hamel et al., 2005). GnRH-like peptides in the testicle and ovary play an inhibitory regulation on steroidogenesis (Franchimont, 1983).

\section{Neuroendocrine signals}

At present there is no doubt that in addition to pituitary and non-pituiraty hormone control, ovarian functions, hormone synthesis and ovulation, as well as adrenal cortex secretions, and perhaps the secretion of hormones by the testicles and even spermatogenesis, are under direct local neural modulation.

Kawakami et al. $(1979,1981)$ obtained the first unequivocal results indicating that the regulation of ovarian functions is accomplished by hormonal signals that are modulated by neural signals. Applying electric stimulation to the ventromedial hypothalamus and the medio-basal prechiasmathic area in hypophysectomized and adrenalectomized rats provoked the release of progesterone and estradiol without modifying ovarian blood flow. The synthesis and secretion of steroids from the adrenal cortex and ovaries are also under direct modulation by local neurons. Without making synaptic contact, many noradrenergic nerve endings are in close proximity to zona-glomerulosa cells. NA acts as a direct modulator of local steroid secretion. Catecholamines and adenosine triphosphate (ATP) 
diffuse into zone glomerulosa cells and modulate the synthesis of aldosterone in a paracrine way. The enzymes that may terminate the effect of ATP are present in the nerve endings, suggesting that ATP and its metabolites influence the production of aldosterone. Thus, catecholamines and ATP play a paracrine non-synaptic modulator role of in the regulation of adrenocortical steroid secretion (Szalay et al., 1998).

Stimulation of beta-adrenoreceptors, VIP receptors or the forskolin-induced activation of cAMP formation of 2-day-old rat ovaries increases the steady state levels of the mRNAs encoding P-450aromatase and FSH receptors. Based on these results it was suggested that ovarian nerves, acting via neurotransmitters coupled to the cAMP generating system, contribute to the differentiation process by which newly formed primary follicles acquire FSH receptors and responsiveness to FSH. Follicles that grow in more densely innervated ovarian regions may have a selective advantage over those not exposed to neurotransmitteractivated, cAMP-dependent signals; and thus may become more rapidly subjected to gonadotropin control (Mayerhofer et al., 1997).

The intra-cerebro-ventricular injection (icv-i) of isoproterenol (beta-adrenergic agonist) to rats in diestrus 2 lowers progesterone levels in the ovarian vein blood. However, no apparent effects are observed when both superior ovarian nerves (SON) are sectioned before the icv-i treatment. Blocking the beta-adrenergic receptors with propranolol icv-i increased progesterone levels, an effect that was not observed when both SONs were sectioned (De Bortoli et al., 1998, 2002). According to De Bortoli et al. (2000), the neural signals arriving to the ovary through the SON antagonize the ovarian $\mathrm{LH}$ regulation of progesterone and androstenedione.

\section{Ovarian and adrenal innervations}

The adrenal gland and the ovaries receive innervation from several nerve fibers of extrinsic and intrinsic origin. Most of the extrinsic innervations in the adrenal derive from the sympathetic nervous system, including cholinergic fibers containing nitric oxide synthase (Holgert et al., 1995), thyrosine hydroxylase- and neuropeptide Y-positive postganglionic sympathetic fibers (Holgert et al., 1998; Kondo, 1985). Encephalin was exclusively found in choline-acethyl-transferase positive fibers among adrenaline chromaffin cells (Holgert et al., 1995). Intrinsic innervation originates from two different types of medullary ganglion cells: Type I and Type II cells. Type I cells are NPY-positive noradrenergic, while type II ganglion cells synthesize VIP and nitric oxide synthase (Holgertet al., 1998; Ulrich-Lai et. al., 2006).

The adrenals have efferent fibers connecting to the dorsal motor nucleus of the vagus nerve, while other fibers of vagal origin reach the gland via the celiac or suprarenal ganglion (Berthoud and Powley, 1993; Coupland et al., 1989). In the rat, the motor and sensory vagal innervations of the adrenal gland originate from bilaterally situated cell bodies that have slight ipsi-lateral predominance (Coupland et al., 1989). Nerve fibers that go to and from the adrenal gland also possess afferent viscero-sensory fibers. According to Tóth et al. (2007), the steroid feedback mechanism affects the cerebral structures that send descending input to the sympathetic preganglionic neurons innervating the adrenal gland.

The bilateral sectioning of the thoracic splanchnic nerve resulted in lower corticosterone plasma levels measured in the afternoon seven days after treatment, without apparent changes in ACTH levels; results that suggest that the splanchnic adrenal innervation modulates the response to ACTH. The effects are related to functional changes in the adrenal medulla and do not depend on the sensitive of the afferent fibers (Ulrich-Lai et al., 2006). 
The ovaries receive motor innervations from the sympathetic and the parasympathetic system via the vagus nerve, and possess afferent fibers travelling sympathetic and vagal routes (Burden et al 1983; Klein and Burden, 1988, Gerendai et al., 2000, 2009). The vagus nerve connects the ovaries with the area postrema, the nucleus of the solitary tract, the dorsal vagal complex, the parapyramidal nucleus, A1, A5, and A7 -cell groups, the caudal raphe nuclei, the hypothalamic paraventricular nucleus, the lateral hypothalamus, the Barrington's nucleus, the locus coeruleus, the periaqueductal gray, and the dorsal hypothalamus. All of these areas form a neural circuit that directly participates in the neural communication between the CNS and the ovaries (Gerendai et al., 2000; Tóth et al., 2007).

As in the adrenals, the ovaries have micro-ganglia with tyrosine hidroxilase positive neurons (D'Albora \& Barcia, 1996; Dees et al., 1995; D'Albora et al., 2002), and along some capillaries there are neurons resting on the basal (D'Albora \& Barcia, 1996).

\section{Methodologies used to analyze the participation of neural signals}

The participation of the peripheral nervous system in the regulation of adrenal, ovarian and testicular functions is studied using two main experimental approaches: in vitro and in vivo methods. Studies in vitro allow for the understanding of the isolated participation of one, two or even three neurotransmitters in the regulation of hormones secretion by one type of cell, or even an organ tissue. Studies in vitro have certain advantages, such as the possibility of analyzing the cellular mechanisms regulated by neurotransmitters, identifying the receptors participating in the regulation, and the molecular changes that occur. In vitro methods also have disadvantages, since in many studies the amount of neurotransmitters added to the culture medium is much higher than the normal concentration measured in the organ. Another problem of in vitro studies is the loss of the interplay occurring between different kinds of cells.

In vivo methods include the analysis of nerve stimulation and/or sectioning, the extirpation of one or both organs, the denervation of the in situ organ, as well as the local or systemic injection of neurotransmitters or blocking agents. The information obtained from in vivo studies gives an idea about the animal's response to such manipulations (changes in hormone levels; metabolic modifications, etc.). In general, the cellular mechanisms participating in the modifications resulting from such manipulations are not clearly evident.

\subsection{In vitro methods}

Taken together, the results of in vitro and in vivo studies give an idea about the participation of neurotransmitters in regulating steroid hormone secretion. Studies on the participation of different systems regulating the secretion of steroid hormones analyze the effects of directly injecting neurotransmitters or substances known to block its receptors. Incubating steroidhormones producing cells, with or without specific neurotransmitters, or in neurotransmitters "cocktails", is the main methodology used for studying the participation of neural signals regulating the secretion of steroid hormones.

Serotonin inhibits testosterone, dihydrotestosterone, and androstane-3alpha, 17beta-diol production from testicles of peripubertal and adult hamsters maintained in long or short photoperiods. Serotonin also inhibits the stimulation induced by hCG, cAMP and testosterone production, by its union to 5-HT1A and 5-HT2A receptors subtypes. The testicular activity of the serotoninergic system is mediated by the corticotrophin releasing 
hormone (CRH) and by the noradrenergic system. CRH has an inhibitory modulation of testosterone, dihydro-testosterone, and androstane-3alpha, 17beta-diol secretion, while epinephrine and norepinephrine have a stimulatory effect through alpha1/beta1-adrenergic receptors (Frungeri et al., 2002).

Stress induced by sleep deprivation results in lower testosterone levels in serum and lower testicular StAR protein expression, while serotonin and corticosterone serum levels are elevated (Wu et al., 2011). These results suggest that serotonin regulation of steroid hormones release depends on the cells where such sterols originate.

Acting through $\beta-1$ and $\beta-2$ receptors, NA stimulates progesterone secretion from luteal slices of heifers, and increases cytochrome P-450scc and 3 beta-HSD activity (Miszkiel \& Kotwica, 2001). Nitric oxide (NO) inhibits the activity of cytochrome P450 aromatase and the secretion of estradiol by granulosa cells in culture (Ishimaru et al., 2001). In vitro studies show that in the rat, the participation of neurotransmitters regulating the secretion of ovarian progesterone varies throughout the day of the estrous cycle. In diestrus-1, NPY, NA, and VIP inhibit progesterone secretion by the ovaries, while on diestrus- 2 these neurotransmitters stimulate progesterone secretion. In diestrus 1 and 2, NA+VIP or NA+NPY had a synergic effect on progesterone secretion, since measured concentrations were higher than VIP or NPY treatment alone (Aguado, 2002). In the rat, ovarian denervation reduces the synthesis and secretion of progesterone by inhibiting 3-betaHSD activity (Burden \& Lawrence, 1977). Sectioning the plexus nerve and the SON of pigs led to lower LH, progesterone, androstenedione (A4), testosterone, estrone and estradiol-17beta plasma levels. In addition, a significant increase in the immune-expression of cholesterol side-chain cleavage cytochrome P450 occurs in follicles, as well as a decrease in 3-betaHSD activity, and in LH, progesterone, androstenedione (A4), testosterone, estrone and estrogen plasma levels (Jana et al., 2007).

Using an ex vivo celiac ganglion (CG)-SON-ovary (CG-SON-O) system, Aguado's research group has contributed to the understanding of the participation of the $\mathrm{SON}$, the plexus ovarian nerve and the vagus nerve in regulating the secretion of ovarian hormones. In in vitro studies, the release of ovarian hormones is modulated by the stimulation/inhibition of neurons present in the CG.

According to Morán et al., (2005), the CG form a bilateral structure with the superior mesenteric ganglia in the rat, receiving the name of celiac-superior mesenteric ganglion (CSMG) which is composed of noradrenergic neurons called principal neurons, small intensely fluorescent cells, and peptidergic interneurons.

In in vitro studies, adding NPY, VIP or substance P (SP) to the ovaries obtained from rats in diestrus 1 resulted in lower release of progesterone, while the same treatment to ovaries obtained from rats in diestrus 2 increased it. Adding these three neuropeptides to the CG from rats in diestrus 2 resulted in higher progesterone secretion (Garraza et al., 2004). These results suggest that the way neural signals participate in the regulation of steroid secretions depends on the day of the estrous cycle and the type of cells receiving the signal.

Adding NA to the CG obtained from rats on diestrus 1 resulted in ovarian dopaminergic and noradrenergic activity increases, while adding NA to the CG system from rats on diestrus 2 only increased noradrenergic activity. Such changes in dopaminergic and noradrenergic ovarian activities resulted in lower release of androstenedione in systems obtained from rats on diestrus 1 , and higher release of androstenedione in systems obtained from rats on diestrus 2 (Bronzi et al., 2011). 
The results presented above suggest that the adrenergic activation of the CG plays a role in regulating ovarian androgen secretion, and that this role varies along the estrous cycle. Therefore, steroidogenesis appears to be controlled by a balance between the stimulatory effects of hormones secreted by the pituitary, the inhibitory effects of other hormones, and the modulating participation of the ovarian innervations.

Pituitary hormones and innervations, including sympathetic and sensory nerves, also regulate the adrenal cortex secretion of hormones. The nerves innervating the adrenal cortex include heterogeneous populations containing various different neuropeptides (Kondo, 1985). The sympathetic innervation is composed of cholinergic preganglionic fibers and catecholaminergic postganglionic fibers that are positive for tyrosine hydroxylase (TH) and NPY (Kondo, 1985; Holgert et al., 1998). Sensory innervations consist of primary afferent fibers that are positive for calcitonin gene-related peptide (CGRP) and SP (Kuramoto et al. 1987). Intrinsic innervations on the adrenal cortex arise from two types of medullar ganglion cells: Type I cells are noradrenergic and NPY-positive, whereas Type II cells produce neuronal nitric oxide synthase and VIP (Holgert et al., 1998). Preganglionic sympathetic and primary afferent fibers are carried in the thoracic splanchnic nerve (Ulrich-Lai \& Engeland 2000).

\section{Experimental methods in vivo}

Figure 1 shows the innervations received by the ovaries and adrenals originating in the CMSG and the centers originating in the vagus nerve (Vagus centers). The CMSG and the

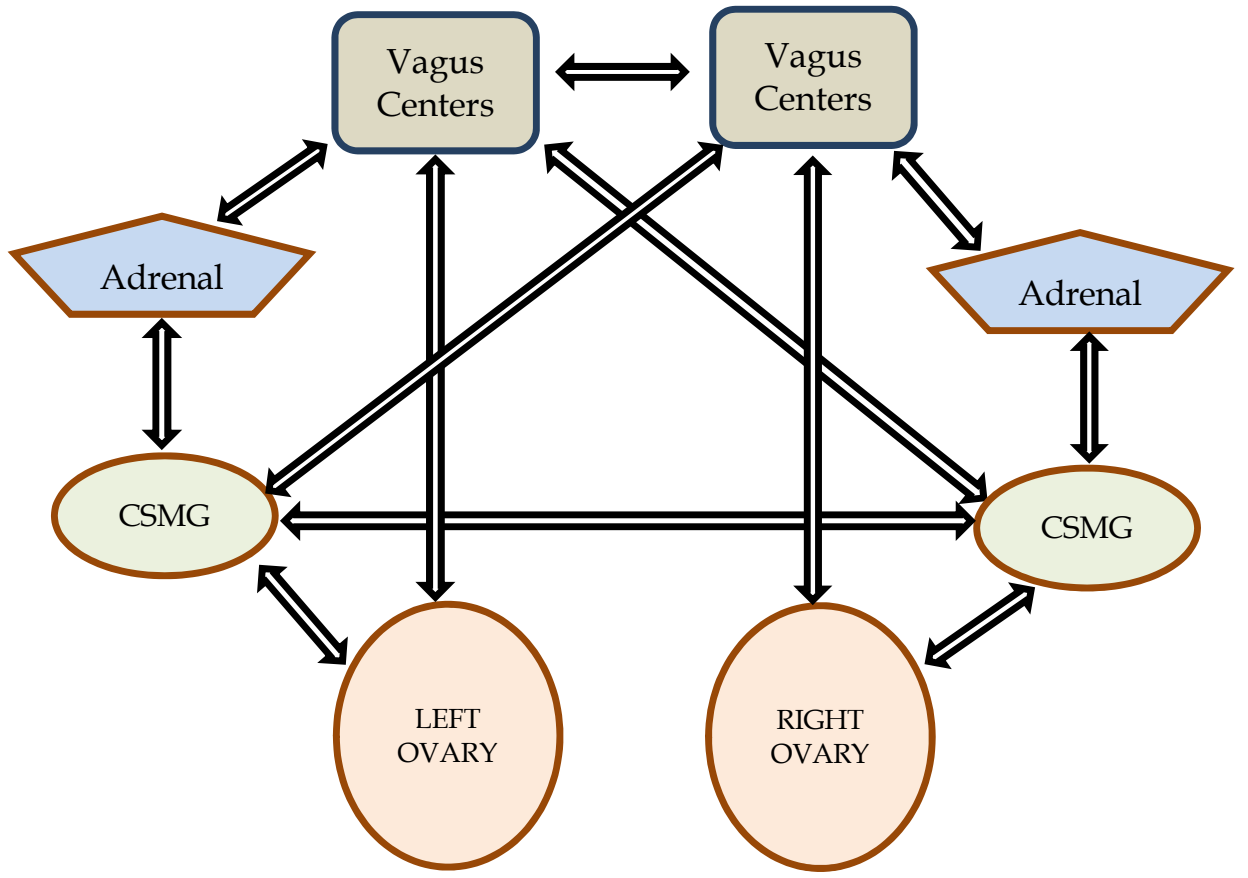

Fig. 1. The diagram shows the neural pathways connecting the adrenals and ovaries with the celiac-superior mesenteric ganglia (CSMG). The interconnections between the right and left CSMG, as well as the innervations to the vagus nerves are also represented. 
vagus centers seem to be the place where information from other regions of the CNS converges. Both centers send and receive neural information that modulates the reactivity of the endocrine cells to hormonal signals from the ovaries and adrenals. The existence of neural communication between the right and left CMSG implies the existence of neural communication between the ovaries. The modulation exerted by the neural signals over the ovaries and the adrenals varies during the estrous cycle (ovaries) and along the day (adrenals and ovaries). Such modulation is asymmetric, and the asymmetry varies during the estrous cycle and the hour of the day.

Extirpating one ovary or one adrenal result in acute neural stimulation of the in situ ovary and/or adrenal, that modifies the response of endocrine cells to the hormonal signals. Sectioning one nerve also results in an acute neural stimulation of the denervated organ, though such stimulation is more restricted. For the ovaries and adrenals, the partially denervated organ still has neural pathways regulating its functions and, in theory, the innervated organ received only one different neural signal.

To study the role played by the ovarian innervations in regulating progesterone, testosterone and estradiol levels in serum we have used five experimental models. The experimental models were performed on cyclic rats and our studies analyzed the influence of the day of the estrous cycle on treatment results.

1. The effects of dorsal and ventral surgery to reach the ovaries and their innervation.

2. The effects of bilateral ovariectomy or adrenalectomy

3. The effects of unilateral ovariectomy

4. The effects of unilateral or bilateral section of the SON

5. The effects of unilateral adrenalectomy.

\subsection{The effects of dorsal and ventral surgical approaches}

The unilateral perforation of the dorsal or ventral abdominal wall results in different changes in progesterone, testosterone and estradiol serum levels. Irrespective of the day of the estrous cycle surgery was performed, rats with a ventral sectioning of the abdominal wall showed higher progesterone and testosterone levels in serum than control rats and rats with dorsal sectioning of the abdominal wall (Figure 2). The increase in hormone release could be explained by an increase in StAR protein phosphorylation and/or synthesis stimulated by the neurotransmitters released by the neural terminals arriving to the ovaries and adrenals. Changes in ACTH, LH and FSH serum levels induced by sectioning the abdominal wall cannot be ruled out. Since estradiol levels were not modified, we presume that $\mathrm{P}-450$ aromatase activity is not influenced by the neural information arising from the abdominal wall.

Uchida et al. (2005) showed the existence of asymmetry in the neural reflexes arising from the abdominal skin that arrive to the ovaries and affect the ovarian blood flow and the activity of the SON. Stimulating the left abdomen produced a much stronger effect on the activity of the left ovarian sympathetic nerve than stimulating the right abdomen. The magnitude of the changes in hormone levels induced by ventral or dorsal surgery depend on both, the dorsal or ventral side (left or right) of the surgery and the day of the estrous cycle when surgery is performed. These results suggest the existence of a multisynaptic neural pathway between the abdominal wall, the adrenals and the ovaries, a pathway that is mediated through the innervations of the adrenals and ovaries (Flores et al., 2008). 


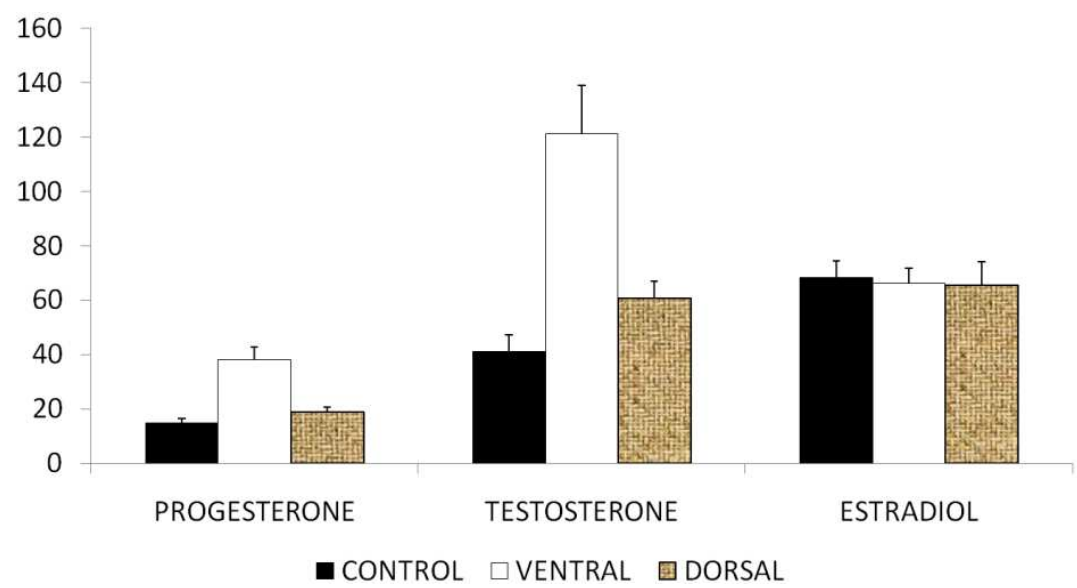

Fig. 2. Comparative effects of ventral or dorsal sectioning the abdominal wall on progesterone, testosterone, and estradiol serum levels. Based in data published by Flores et al., (2008) * $\mathrm{p}<0.05$ vs. control (MANOVA followed by Tukey's test)

\subsection{The effects of bilateral ovariectomy or adrenalectomy performed using a dorsal or ventral approach}

Compared to animals with a ventral abdominal wall surgery, the effects of ventral bilateral ovariectomy one hour after surgery include lower testosterone and estradiol levels; while ventral bilateral adrenalectomy resulted in lower the progesterone levels (Figure 3). Similar effects were observed when surgeries were performed using the dorsal approach.

The effects of bilateral ovariectomy depend on the day of the cycle when surgery is performed (Flores et al., 2008). For instance, ventral bilateral ovariectomy on diestrus 1 resulted in lower progesterone levels than in animals with ventral wall surgery. These effects were not observed when the treatment was performed on diestrus 2, proestrus or estrus. In turn, dorsal bilateral ovariectomy on proestrus or estrus resulted in higher progesterone levels in serum than in rats with ventral abdominal wall surgery. The effects of bilateral adrenalectomy on progesterone were not impacted by the day of the cycle when surgery was performed or by the surgical approach (Flores et al., 2008). These results suggest that the neural information arriving to the adrenals and ovaries play different roles in regulating progesterone secretion by both organs.

Compared to ventral approach wall surgery treatment, animals with ventral bilateral ovariectomy had lower testosterone serum levels on each day of the estrous cycle. Similarly, ventral bilateral adrenalectomy performed on estrus resulted in lower hormone levels. Testosterone levels were not modified when the adrenals were removed on diestrus 1 , diestrus 2 or proestrus. Compared to animals with dorsal wall surgery treatment, testosterone serum levels were lower in rats with dorsal bilateral ovariectomy performed on diestrus 2 or proestrus and higher when treatment was performed on estrus (Flores et al., 2008).

Compared to ventral or dorsal abdominal wall surgery treatment, ventral or dorsal bilateral ovariectomy performed on proestrus resulted in lower estradiol serum levels. Ventral bilateral adrenalectomy performed on diestrus 1 or 2 resulted in higher hormone levels, and 
lower when surgery was performed using a dorsal approach; and an inverse result occurred when the animals were treated on estrus (Flores et al., 2008).

Bilateral ovariectomy and adrenalectomy modify progesterone, testosterone and estradiol serum levels depending on the day of the cycle and the surgical approach. Analyzing the effects of dorsal or ventral bilateral ovariectomy or adrenalectomy on progesterone, testosterone and estradiol levels, suggest that the stimulatory/inhibitory signals arising from the dorsal or ventral abdominal wall modifies the sensitivity of the theca interna and granulosa cells to the hormonal signals regulating their functions.

The results obtained from rats with bilateral ovariectomy or adrenalectomy suggests that the ovaries mainly produce testosterone and estradiol, while the adrenals are the main producer of progesterone. The effects of bilateral adrenalectomy performed on different days of the estrous cycle on testosterone and estradiol serum levels (Flores et al., 2008) suggest that endocrine signals arising from the adrenals (corticosterone and progesterone) play a role regulating ovarian steroids release. It is possible that at the CSMG level, bilateral adrenalectomy modified the functions of the neurons originating in the $\mathrm{SON}$ and the nerve of the ovarian plexus that innervate the ovaries.

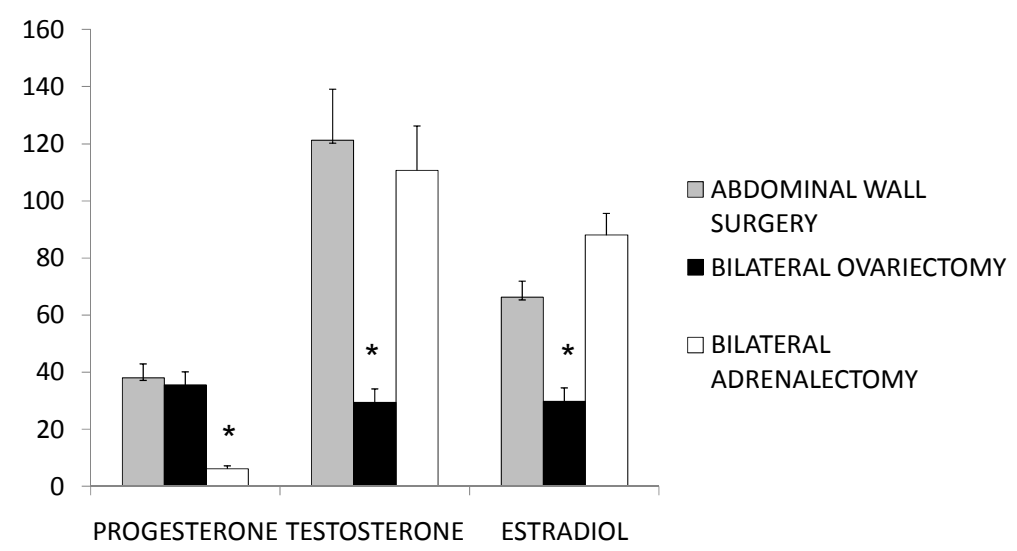

Fig. 3. Comparative effects of ventral bilateral ovariectomy or ventral adrenalectomy on progesterone, testosterone and estradiol serum levels. Based on data published by Flores et al., (2008) * p<0.05 vs. abdominal wall surgery (MANOVA followed by Tukey's test)

\subsection{The effects of unilateral ovariectomy}

The acute effects of hemiovariectomy on progesterone, testosterone, estradiol, and LH concentrations in serum depends on the surgical approach and the day of the cycle when surgery is performed (Barco et al., 2003; Flores et al., 2005, 2006, 2011; Cruz et al., 2006).

Figure 4 shows the comparative effects of ventral unilateral mechanical stimulation of the SON and unilateral ventral ovariectomy, performed on each day of the estrous cycle, on progesterone, testosterone and estradiol serum levels analyzed one hour after treatment. The ventral mechanical stimulation of the left or right SON of rats in estrus resulted in higher progesterone levels. While extirpating the left ovary eliminated the progesterone levels increase, extirpating the right ovary did not. Regardless of the day of the estrus cycle 


\section{Progesterone}

\section{Testosterone}
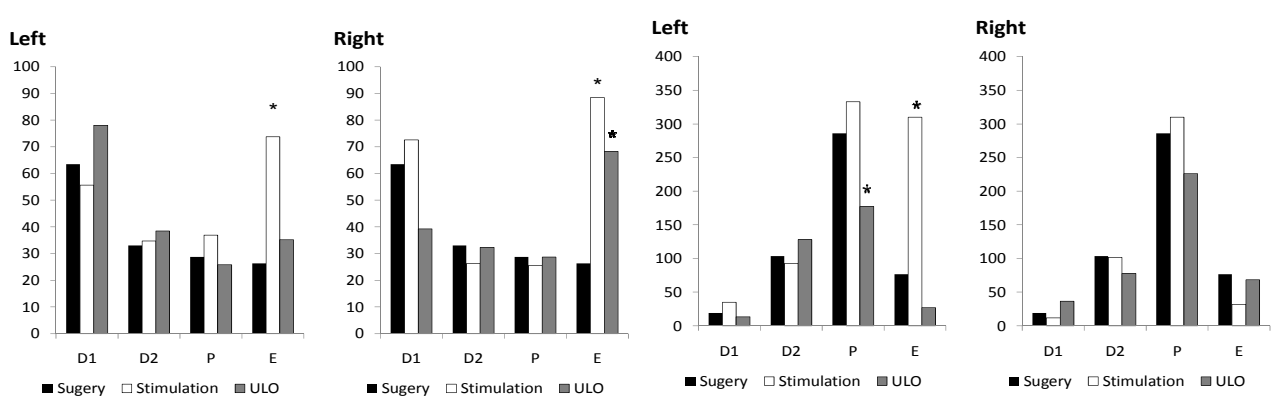

\section{Estradiol}
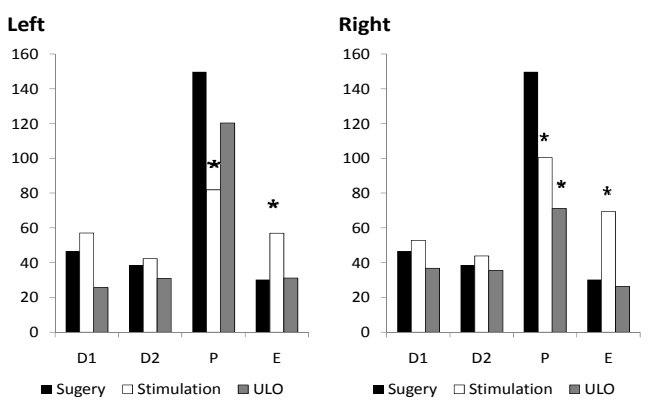

Fig. 4. Comparative effects of ventral unilateral mechanical stimulation of the SON and ventral unilateral ovariectomy performed each day of the estrous cycle on: progesterone $(\mathrm{ng} / \mathrm{mL})$, testosterone and estradiol $(\mathrm{pg} / \mathrm{mL})$ one hour after surgery. ${ }^{*} \mathrm{p}<0.05$ vs. surgery. Ventral surgery; $\square$ mechanical stimulation of the SON; $\square$ unilateral ovariectomy (ULO)

rats were treated on, stimulating the left SON resulted in higher testosterone levels, while stimulating the right SON did not have an apparent effect on testosterone. Higher testosterone levels in serum resulting from the stimulation of the left SON were eliminated when the right ovary was subsequently removed. In rats on estrus, stimulating the left or right $\mathrm{SON}$ increased estradiol levels, and ventral ovariectomy eliminated it.

These results suggest that mechanically stimulating the SON on estrus day stimulates the transport of cholesterol to the mitochondria, and the performance of the enzymes participating in the synthesis of progesterone and estradiol in both ovaries. Effects on testosterone levels were observed only when the left ovary was manipulated, suggesting an asymmetric participation of the ovarian innervation in regulating testosterone, and that such asymmetry depends on the day of the estrous cycle.

In other studies, the acute and non-acute effects of dorsal unilateral ovariectomy on progesterone, testosterone and estradiol serum levels vary according to the time elapsed between surgery and autopsy (Morales et al., 2011). 


\subsection{The effects of unilateral or bilateral ovarian denervation}

The ovaries receive innervations arriving through the $\mathrm{SON}$, the ovarian plexus nerve, and the vagus nerve. Since each nerve carries different neural information, we postulate that the unilateral or bilateral sectioning of each nerve will produce different effects on the secretion of steroid hormones by the ovaries.

The SON and the ovarian plexus nerve carry catecholaminergic fibers that innervate endocrine ovarian cells. These fibers are distributed in the peri-follicular theca layer and are closely related to the theca internal cells. According to Burden (1978) and Aguado (2002), most neurons originating in the SON fibers are located in the CSMG. Aside from the catecholaminergic innervation, the SON provides VIP (Garraza et al., 2004) and NO (Casais et al., 2007) innervations to the ovaries. 24 and $72 \mathrm{hrs}$ after unilateral or bilateral sectioning of the SON of pre-pubertal rats, NA levels in the denervated ovary were lower than in untouched (control) or laparotomized animals (Chávez et al., 1994).

Aguado \& Ojeda (1984) observed that after sectioning both SON on proestrus the secretion of progesterone and estradiol from both ovaries dropped immediately (four minutes). Progesterone secretion was recovered 15 minutes later, but estradiol levels kept low. Sectioning the SON on estrus did not modify hormone secretion. The effects of denervation depended on the hour of the day when surgery was performed. According to the authors, their results support the idea that the CNS controls directly the hormone release by the ovaries.

In gilts, sectioning the plexus and the SON during the middle luteal phase of the estrous cycle lowered the number of dopamine-beta-hydroxylase- and/or neuropeptide tyrosineimmunereactive nerve terminals. The treatment also lowered the levels of progesterone, androstenedione, and testosterone in the fluid and the wall of follicles. Neurectomy increased the immune expression of cholesterol side-chain cleavage cytochrome P450, lowered the expression of 33-hydroxysteroid dehydrogenase, and lowered the plasma levels of LH, progesterone, androstenedione, testosterone, estrone and estradiol-17beta. The results suggest that ovarian innervations play a role regulating the steroidogenic activity of the ovary (Jana et al., 2007).

Figure 5 shows the comparative effects of ventral unilateral mechanical stimulation of the SON on ovarian hormone secretion. From the graph, it is apparent that progesterone and testosterone levels in serum were modified by mechanically manipulating the SON, while changes in estradiol serum levels are not significant.

As with unilateral ovariectomy, the acute effects of ventral unilateral sectioning of the SON on progesterone, testosterone and estradiol serum levels presents asymmetry and vary according the day of the cycle when surgery was performed (Flores et al., 2011).

Ovarian denervation performed by unilaterally sectioning the vagus nerve, by a ventral approach, has different effects on normal cyclic rats and ULO rats. Sectioning the left vagus nerve resulted in lower ovulation rates than in sham operated animals; while sectioning the right vagus nerve did not modify ovulation rates. Sectioning the right or left vagus nerves to right-ULO rats (left ovary in-situ) reduced compensatory ovarian hypertrophy. Sectioning the left vagus nerve to ULO rats induced different effects depending on which ovary remained in-situ. Left-side vagotomy performed to right ULO rats (left ovary in-situ) resulted in higher ovulation rates, compensatory ovarian hypertrophy, and number of ova shed; while the same procedure to left ULO rats (right ovary in-situ) resulted in a decrease of the same parameters. 


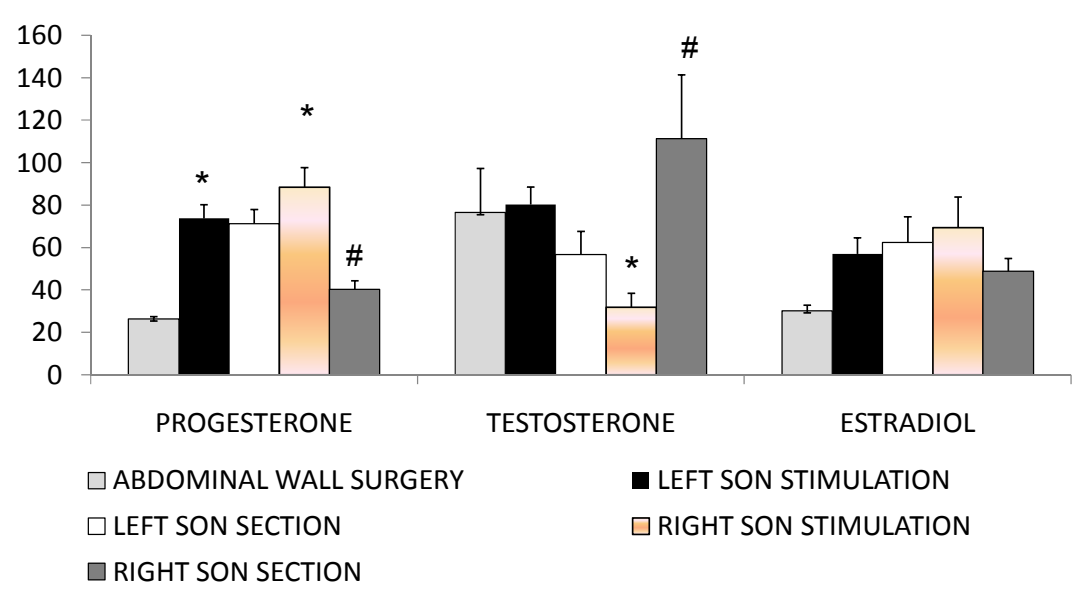

* $\mathrm{p}<0.05$ vs. abdominal wall surgery; \# $\mathrm{p}<0.05$ vs. ipsilateral stimulation (MANOVA followed by Tukey's test)

Fig. 5. Comparative effects of ventral abdominal wall surgery, unilateral stimulation or sectioning of the superior ovarian nerve on progesterone $(\mathrm{ng} / \mathrm{mL}$, testosterone and estradiol serum levels $(\mathrm{pg} / \mathrm{mL})$.

Sectioning the right or left vagus nerves to right-ULO rats (left ovary in-situ) reduces compensatory ovarian hypertrophy, while the effects of sectioning the left vagus nerve depended on which ovary remained in-situ. Left-side vagotomy performed to right ULO rats (left ovary in-situ) resulted in higher ovulation rates, higher compensatory ovarian hypertrophy, and higher number of ova shed; while the same procedure to left ULO rats (right ovary in-situ) resulted in lower levels of the same parameters (Chávez et al.1987, 1989).

Sensorial innervations also play a role in regulating ovarian functions. Sensorial denervation induced by injecting capsaicin subcutaneously or into the ovarian bursa lowered spontaneous ovulation and secretion of progesterone and estradiol. Capsaicin treatment to ULO rats affected ovulation and the secretion of ovarian steroids, and these effects depended on which ovary remained in situ and the day of the cycle when treatment was performed (Trujillo et al., 2001, 2004).

\subsection{The effects of unilateral adrenalectomy}

Figure 6 shows the acute effects (one hour after surgery) of unilateral adrenalectomy, conducted on each day of the estrous cycle, on progesterone, testosterone and estradiol serum levels. The results show that the lack of one adrenal modified in different ways the concentration of the three hormones. The results suggest that the acute diminution and recovery of adrenal hormones affects the transportation of cholesterol to the ovaries in different ways, and the hormone secretion by the in situ ovary is only affected in diestrus 1 , when unilateral adrenalectomy resulted in lower progesterone levels.

The effects of unilateral ovariectomy on testosterone and estradiol serum levels are asymmetric, mostly when surgery was performed on diestrus 2 (testosterone) or proestrus (testosterone and estradiol). The results suggest that the activity of enzymes participating in the synthesis of testosterone and estradiol are regulated by the levels of adrenal hormones and are not related to the synthesis of progesterone, since progesterone levels were not modify when the surgery was performed on diestrus 2 or proestrus. 


\section{Progesterone}
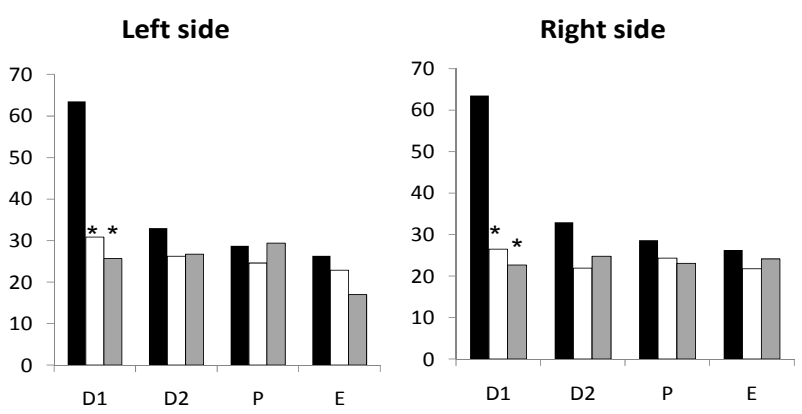

\section{Testosterone}
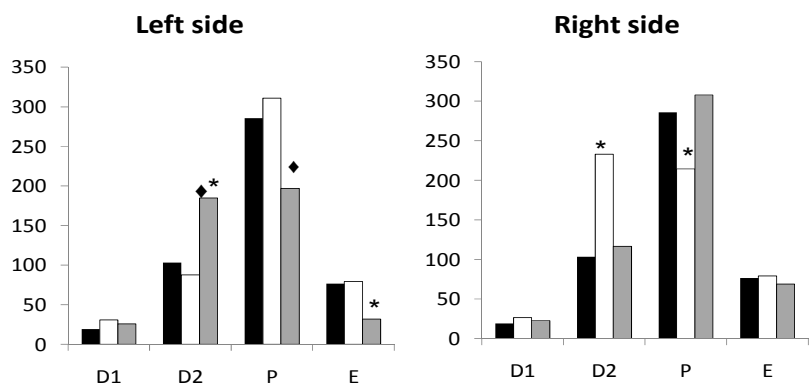

\section{Estradiol}

Left side

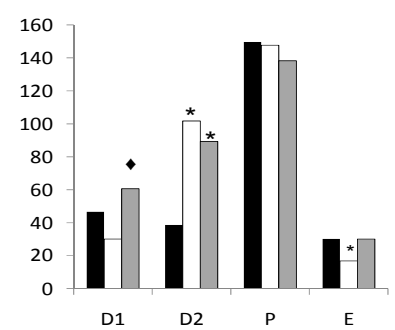

Right side

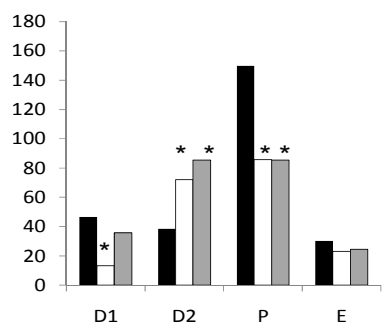

Fig. 6. Comparative effects of ventral unilateral adrenalectomy and ventral unilateral adrenalectomy followed by sectioning the SON ipsilateral to the extirpated adrenal, performed on each day of the estrous cycle on: progesterone $(\mathrm{ng} / \mathrm{mL})$, testosterone and estradiol $(\mathrm{pg} / \mathrm{mL})$ one hour after surgery. ${ }^{*} \mathrm{p}<0.05$ vs. surgery. $\square$ Ventral surgery; $\square$ unilateral adrenalectomy; $\square$ unilateral ovariectomy followed by the SON section. 
Some of the effects of unilateral adrenalectomy seem to be related to the SON ovarian innervation since the unilateral section of the SON modified some of the changes in testosterone and estradiol serum levels induced by unilateral adrenalectomy. Thus, the extirpation of one adrenal could modify the activity of the neurons in the CSMG originating SON fibers.

\section{Ovarian and adrenal asymmetries}

The supra-spinal innervations of the adrenals and ovaries show left side predominance, and some neurons exclusively innervate a given organ (Gerendai et al., 2009). Each adrenal gland is innervated both by side-specific neurons and by neurons that project to both organs (Tóth et al., 2007). The left and right ovaries have different abilities to spontaneously release oocytes. Such differences appear to be related to the ovarian innervations, and the left ovary appears to be more competent to spontaneously release oocytes (Domínguez et al., 1989).

According to Klein and Burden (1988), the number of neural fibers received by the right ovary is higher than in the left; while Toth et al., (2007) showed that the left ovary sends more neural information to the CNS than the right ovary. The right and left ovaries show different ovulatory responses to surgical denervation, and these responses vary according to the day of the estrous cycle when surgery is performed (Chávez et al., 1987, 1989; Chávez \& Domínguez, 1994). These results suggest that the endocrine performances by the ovaries and adrenals present asymmetries, which are related to the innervations received by the organs.

\section{Conclusions}

Taken together the results obtained by different experimental approaches show that the synthesis and release of hormone by the adrenals and ovaries are under multiple controls. The hormonal signals arise from different sources, including the adrenals and ovaries. The adrenal and ovarian innervations modulate the effects of the hormonal signals, possibly by differences in the frequency and amplitude release of different neurotransmitters.

Because the mechanisms regulating the release of steroid hormones changes during the estrous cycle and throughout the day, it is possible that circadian signals arising from the suprachiasmatic nucleus exert a fine modulation of adrenal and ovarian cells to hormone and neural signals (Buijs et al.,2006).

Currently we do not have a clear hypothesis to explain why the organs secreting steroid hormones are asymmetric, or why such asymmetry varies during the estrous cycle and the hour of the day. Questions arising in the intent to present a hypothesis include:

1. Is the expression of hormones and/or neurotransmitters receptors secreted by endocrine cells under the control of proteins synthesized under the directions of the clock genes present in the cells?

2. Do the release characteristics (frequency and amplitude) of neurotransmitters by the axons arriving to the endocrine cells vary during the day, and do they present differences between one organ and the other?

3. What are the functions of the micro-ganglia in the adrenals, testicles and ovaries? 


\section{Acknowledgments}

We thank MSc Álvaro Domínguez-González for assistance in the English revision. DGAPAUNAM Grants IN 200405, IN209508 and IN218911-3 supported the studies whose results are presented herein.

\section{References}

Aguado, L. I. (2002). Role of the central and peripheral nervous system in the ovarian function. Microscopy Research and Technique, Vol. 59, No.1 (December 2002), pp. 462 473, ISSN 1097-0029.

Aguado, L. I. \& Ojeda, S. R. (1984) Ovarian adrenergic nerves play a role in maintaining preovulatory steroid secretion. Endocrinology, Vol. 114, No 5, (May 1984), pp. 19441946, ISSN 0013-7227.

Auchus, R. J. \& Miller, W. L. (2000). The principles, pathways and enzymes of human steroidogenesis. In Endocrinology Fourth Edition Edited by LJ De Groot and JL Jameson. Vol 3, Chap. 115, pp. 1616-1631. ISBN 0-7216-7840-8 (set). WB Saunders Co.

Azhar, S., Leers-Sucheta, S, \& Reaven, E. (2003). Cholesterol uptake in adrenal and gonadal tissues: the SR-BI and 'selective' pathway connection. Frontiers in Bioscience, Vol. 8 , (September 2003) pp. 8,s998-1029, ISSN 1093-4715.

Barco, A. I., Flores, A., Chavira, R., Damian-Matsumura, P., Dominguez, R. \& Cruz, M. E. (2003). Asymmetric effects of acute hemiovariectomy on steroid hormone secretion by the in situ ovary. Endocrine, Vol. 21, No.3 (August 2003), pp. 209-215, ISSN: 15590100 .

Barkan, D., Jia, H., Dantes, A., Vardimon, L., Amsterdam, A. \& Rubinstein M. (1999). Leptin modulates the glucocorticoid-induced ovarian steroidogenesis. Endocrinology, Vol. 140, No. 4, (April 1999), pp. 1731-1738, ISSN 1945-7170.

Barreiro, M. L. \& Tena-Sempere, M. (2004). Ghrelin and reproduction: a novel signal linking energy status and fertility? Molecular and Cellular Endocrinology, Vol. 226, No.1-2, (October 2004), pp. 1-9, ISSN 0303-7207.

Belgorosky, A., Baquedano, MS., Guercio, G. \& Rivarola ,M. A. (2008). Adrenarche: postnatal adrenal zonation and hormonal and metabolic regulation. Hormone Research, Vol. 70, No.5, (September 2008), pp. 257-67, ISSN 0301-0163.

Belloni, A.S., Malendowicz, L. K., Rucinski, M., Guidolin, D. \& Nussdorfer, G. G. (2007). Galanin stimulates cortisol secretion from human adrenocortical cells through the activation of galanin receptor subtype 1 coupled to the adenylate cyclasedependent signaling cascade. International Journal of Molecular Medicine, Vol.20, No.6, (December 2007), pp. 859-864, ISSN 1107-3756.

Berthoud HR, Powley TL. (1993). Characterization of vagal innervation to the rat celiac, suprarenal and mesenteric ganglia. J Journal of the autonomic nervous system.Vol. 42, No. 2 (February), pp.153-169. ISSN 1872-7484

Boon, W. C., Chow, J. D. \& Simpson, E. R. (2010). The multiple roles of estrogens and the enzyme aromatase. In Neuroendocrinology: The Normal Neuroendocrine System, Edited by Luciano Martini, George Chrousos, Fernand Labrie, Karel Pacak, Donald Pfaff, Progress in Brain Research. Vol.181, pp. 209-232, ISBN 13: 978-0-444-53617-4 Elsevier. 
Brannian, J.D., Zhao, Y., \& McElroy, M. (1999). Leptin inhibits gonadotrophin-stimulated granulosa cell progesterone production by antagonizing insulin action. Human Reproduction, Vol.14, No. 2 (June 1999), pp.1445-1448, ISSN 1460-2350.

Bronzi, D., Orozco, A.V., Delgado, S.M., Casais, M. \& Rastrilla, A.M.,\& Sosa, Z.Y. (2011.) Modulation of the noradrenergic activity index by neural stimulus, and its participation in ovarian androstenedione release during the luteal phase. Fertility $\mathcal{E}$ Sterility, Vol. 95, No.4, ( December 2010), pp. 1211-1216, ISSN 0015-0282.

Burden, H.W., Lawrence, I.E. Jr. (1977). The effects of denervation on the localization of delta5-3beta-hydroxysteroid dehydrogenase activity in the rat ovary during pregnancy. Acta Anat (Basel). Vol. 97, No. 3 (March), pp. 286-290. ISSN 0001-5180.

Burden, H.W., Leonard,M, Smith, C,P., Lawrence, I. E. Jr. (1983). The sensory innervation of the ovary: a horseradish peroxidase study in the rat. The Anatomical Record. Vol.207, No. 4 (December), pp. 623-627. 0003-276X.

Buijs, R.M., Scheer, F.A., Kreier, F., Yi, C., Bos, N., Goncharuk, V.D. \& Kalsbeek A. (2006) Organization of circadian functions: interaction with the body. Progress in Brain Research, Vol. 153 , No., (2006), pp. 341-360. Hypothalamic Integration of Energy Metabolism, Proceedings of the 24th International Summer School of Brain Research, held at the Royal Netherlands Academy of Arts and Sciences Amsterdam, The Netherlands 29 August-01 September 2005. Edited by: A. Kalsbeek, E. Fliers, M.A. Hofman, D.F. Swaab, E.J.W. van Someren and R.M. Buijs ISBN 978-0-444-52261-0.

Caminos, J. E., Nogueiras, R., Gaytán, F., Pineda, R., González, C.R., Barreiro, M.L., Castaño, J.P., Malagón, M.M., Pinilla, L., Toppari, J., Diéguez, C. \& Tena-Sempere, M. (2008). Novel expression and direct effects of adiponectin in the rat testis. Endocrinology, Vol. 149, No. 7, (July 2008), pp. 3390-3402, ISSN 1945-7170.

Casais, M., Delgado, S.M., Vallcaneras, S., Sosa Z., \& Rastrilla, A.M. (2007). Nitric oxide in prepubertal rat ovary contribution of the ganglionic nitric oxide synthase system via superior ovarian nerve. Neuroendocrinology letters, Vol. 28, No. 1, (February), pp. 39-44, ISSN 0172-780X.

Chávez, R., Cruz, M.E. \& Domínguez, R. (1987). Differences in the ovulation rate of the right or left ovary in unilaterally ovariectomized rats: effect of ipsi- and contralateral vagus nerves on the remaining ovary. Journal of Endocrinology, Vol.113, (June 1987), pp. 397-401, ISSN 0022-0795.

Chávez, R., Morales, L., Gonzalez, M. E. \& Domínguez, R. (1994). Ovarian norepinephrine content in prepubertal rats with superior ovarian nerve section. Temporally studies. Medical Science Research 1994, Vol.22, (n.d.), pp.789-790, ISSN .

Chávez, R., Sánchez, S., Ulloa-Aguirre, A. \& Domínguez, R. (1989). Effects on estrous cyclicity and ovulation of unilateral section of the vagus nerve performed on different days of the estrous cycle in the rat. Journal of Endocrinology ,Vol.123 , No.3, (December 1989), pp. 441-444,ISSN 0022-0795.

Chen, M. C., Wang S.W., Kan S.F., Tsai S.C., Wu Y.C. \& Wang P. S. (2010) Stimulatory effects of propylthiouracil on pregnenolone production through upregulation of steroidogenic acute regulatory protein expression in rat granulosa cells. Toxicological Sciences, Vol.118, No.2, (October 2010), pp. 667-74, ISSN 1096-0929.

Chrenek, P., Grossmann, R. \& Sirotkin, A. V. (2010). The cAMP analogue, dbcAMP affects release of steroid hormones by cultured rabbit ovarian cells and their response to 
FSH, IGF-I and ghrelin. European Journal of Pharmacology, Vol. 640, No.1-3, (August 2010), pp. 202-205, ISSN 0014-2999.

Chung. S., Son, G.H., \& Kim, K. (2011). Circadian rhythm of adrenal glucocorticoid: its regulation and clinical implications. Biochimica et biophysica acta,Vol.1812, No. 5, (May), pp. 581-591. ISSN 0006-3002.

Coupland, R. E., Parker, T. L., Kesse, W. K. \& Mohamed, A. A. (1989). The innervation of the adrenal gland. III. Vagal innervation. Journal of Anatomy, Vol.163 , (April 1989), pp. 173-181, ISSN 1469-7580.

Cruz, M. E., Flores, A., Palafox, M. T., Meléndez, G., Rodríguez, J. O., Chavira, R. \& Domínguez R. (2006). The role of the muscarinic system in regulating estradiol secretion varies during the estrous cycle: the hemiovariectomized rat model. Reproductive Biology and Endocrinology, (August 2010), pp. 4-43, ISSN 1945-7170.

Cunningham, L. A. \& Holzwarth, M. A. (1988). Vasoactive intestinal peptide stimulates adrenal aldosterone and corticosterone secretion. Endocrinology. Vol. 122, No. 5, (May 1988), pp. 2090-2097, ISSN 0013-7227.

Czajka-Oraniec, I. \& Simpson, E. R. (2010). Aromatase research and its clinical significance. Endokrynolia Polska, Vol.61, No.1, (February 2010), pp. 126-34, ISSN 0423-104X.

D'Albora, H. \& Barcia, J. J. (1996). Intrinsic neuronal cell bodies in the rat ovary. Neurosciense Letters, Vol.205, No.1, (1996), pp. 61-67, ISSN 0304-3940.

D'Albora, H., Anesetti, G., Lombide, P., Dees, W.L. \& Ojeda, S.R.(2002). Intrinsic neurons in the mammalian ovary. Microscopy Research Technology. Vol.59, No. 6 (December 15), pp. 484-489.ISSN 1097-0029.

De Bortoli, M.A., Garraza, M.H., \&Aguado, L. I. (1998). Adrenergic intracerebroventricular stimulation affects progesterone concentration in the ovarian vein of the rat: participation of the superior ovarian nerve. Journal of Endocrinology, Vol. 159, No.9, (October 1998), pp. 61-68, ISSN 0022-0795.

De Bortoli, M. A, Garraza, M. H., \& Aguado, LI. (2000). Epinephrine intracerebroventricular stimulation modifies the LH effect on ovarian progesterone and androstenedione release. Journal of Steroid Biochemistry \& Molecular Biology, Vol. 74, No.1-2, (September 2000), pp.19-24, ISSN 0960-0760.

De Bortoli, M. A., Garraza, M. H., \&Aguado, L. I. (2002). Involvement of beta-adrenoceptors in a central regulation of the ovarian progesterone release in rats. Neuroendocrinology Letters Vol.23 , No.3, (February 2002), pp. 27-31, ISSN 0172$780 X$.

Dees WL, Hiney JK, Schultea TD, Mayerhofer A, Danilchik M, Dissen GA, Ojeda SR. (1995). The primate ovary contains a population of catecholaminergic neuron-like cells expressing nerve growth factor receptors. Endocrinology, Vol. 136, No.12, (December 1995, pp. 5760-5768, ISSN 0013-7227.

Delarue, C., Conlon, J. M., Remy-Jouet, I., Fournier, A., \& Vaudry, H. (2004). Endothelins as local activators of adrenocortical cells. Journal of Molecular Endocrinology, Vol.32, No.1, (February 2004), pp. 1-7, ISSN 0952-5041.

Diaz, F.J., Anderson, L.E., Wu, Y. L., Rabot, A., Tsai, S. J. \& Wiltbank, M. C.(2002). Regulation of progesterone and prostaglandin F2alpha production in the CL. Molecular Cell Endocrinology, Vol. 191, No. 1 (May 2002), pp. 65-80.ISSN 1872-8057.

Domínguez, R., Cruz, M. E. \& Chávez, R. (1989). Differences in the ovulatory ability between the right and left ovary are related to ovarian innervation. In: Growth 
Factors and the Ovary. Editor Anne M.Hirshfield.. Chap. 39. pp.321-325. Plenum Press, New York

Domínguez, R., Morales, L. \& Cruz, M.E. (2003). Ovarian asymmetry. Annual Review of Biological Sciences. Vol.5, No. Pp. 95-104

Duggal, P.S., Ryan, N.K., Van der Hoek, K.H., Ritter, L.J., Armstrong, D.T., Magoffin, D.A., \& Norman R.J. (2002) Effects of leptin administration and feed restriction on thecal leucocytes in the preovulatory rat ovary and the effects of leptin on meiotic maturation, granulosa cell proliferation, steroid hormone and PGE2 release in cultured rat ovarian follicles. Reproduction, Vol. 123, No.6, (June 2002), pp. 891-898, ISSN 1470-1626.

Dupont, J., Chabrolle, C., Ramé, C., Tosca, L., \& Coyral-Castel, S. (2008). Role of the peroxisome proliferator-activated receptors, adenosine monophosphate-activated kinase, and adiponectin in the ovary. PPAR Research, Vol. 2008, p. 176275 , ISSN $1687-4765$.

Enyedi, P., Szabó, B. \& Spät, A. (1983) Failure of vasoactive intestinal peptide to stimulate aldosterone production. Acta Physiologica Hungarica. Vol. 61, No. 1-2, (n.d.)pp. 7779.ISSN 0231-424X

Espenshade, P. J, \& Hughes, A.L. (2007). Regulation of sterol synthesis in eukaryotes. Annual Review of Genetics, Vol.41, (July 2007), pp. 401-427, ISSN: 0066-4197.

Flores, A., Gallegos, A. I., Velasco, J., Mendoza, F. D., Montiel, C., Everardo, P. M., Cruz, M. E., Domínguez, R. (2008). The acute effects of bilateral ovariectomy or adrenalectomy on progesterone, testosterone and estradiol serum levels depend on the surgical approach and the day of the estrous cycle when they are performed. Reproductive Biology and Endocrinology, Vol. 6. (October 2011), p. 48, ISSN 1945-7170.

Flores, A., Meléndez, G., Palafox, M. T., Rodríguez, J., Barco, A. I., Chavira, R., Domínguez, R. \& Cruz, M. E. (2005). The participation of the cholinergic system in regulating progesterone secretion through the ovarian-adrenal crosstalk varies along the estrous cycle. Endocrine, Vol. 28, No.2, (July 2005), pp. : 145-151, ISSN 1559-0100.

Flores, A., Rodríguez, J. O., Palafox, M. T., Meléndez, G., Barco, A. I., Chavira, R., Cruz, M. E. \& Domínguez, R. (2006). The acute asymmetric effects of hemiovariectomy on testosterone secretion vary along the estrous cycle. The participation of the cholinergic system. Reproductive Biology and Endocrinology, Vol. 4, (March 2006), p. 11, ISSN 1945-7170.

Flores, A., Velasco, J., Gallego,s A. I., Mendoza, F. D., Everardo, P. M., Cruz, M. E. \& Domínguez, R. (2011). Acute effects of unilateral sectioning the superior ovarian nerve of rats with unilateral ovariectomy on ovarian hormones (progesterone, testosterone and estradiol) levels vary during the estrous cycle. Reproductive Biology and Endocrinology, Vol. 9, No.34, (March 2011), pp. , ISSN 1945-7170.

Franchimont, P. (1983). Regulation of gonadal androgen secretion. Hormone Research, Vol.18, No. 1-3, pp.7-17, ISSN 1423-0046.

Frungieri, M. B., Zitta, K., Pignataro, O. P., Gonzalez-Calvar, S. I. \& Calandra, R. S. (2002). Interactions between testicular serotoninergic, catecholaminergic, and corticotropin-releasing hormone e systems modulating cAMP and testosterone production in the golden hamster. Neuroendocrinology. Vol.17, No.1, (July 2002), pp. 35-46, ISSN 0028-3835. 
Garraza, M. H., Aguado, L. I., \& De Bortoli, M. A. (2004) In vitro effect of neuropeptides on ovary or celiac ganglion affects the release of progesterone from ovaries in the rat. Medical Science Monitor, Vol.10, No.12, (December 2004), pp.440-446, ISSN 16343750 .

Gerendai, .I, Tóth, I.E., Boldogköi, Z., Medveczky, I., \& Halász B. (2000) CNS structures presumably involved in vagal control of ovarian function. Journal of Autonomic Nervous System. Vol. 80, No. 1-2, (April 12), pp. 40-45.ISSN 0165-1838

Gerendai, I., Tóth, I.E., Boldogkoi, Z. \& Halász, B. (2009). Recent findings on the organization of central nervous system structures involved in the innervation of endocrine glands and other organs; observations obtained by the transneuronal viral double-labeling technique. Endocrine, Vol.36, No.2, (October 2009), pp. 179188, ISSN 1559-0100.

Ghosh, D., Griswold J, Erman M. \& Pangborn W. (2009). Structural basis for androgen specificity and oestrogen synthesis in human aromatase. Nature, Vol.457 , No.7226, ( January 2009), pp. 219-223 , ISSN 0028-0836.

Hamel, M., Vanselow, J., Nicola, E.S. \& Price CA. (2005). Androstenedione increases cytochrome P450 aromatase messenger ribonucleic acid transcripts in nonluteinizing bovine granulosa cells. Molecular Reproduction and Development. Vol. 70, No. 2, (February 2005), pp.175-183. ISSN 1098-2795

Hinson, J.P., Kapas, S., Orford, C.D. \& Vinson, G.P. (1992). Vasoactive intestinal peptide stimulation of aldosterone secretion by the rat adrenal cortex may be mediated by the local release of catecholamines. The Journal of Endocrinology. Vol. 133, No.2 (May 1992), pp.253-238,ISSN 1479-6805

Holgert, H., Aman, K., Cozzari, C., Hartman, B.K., Brimijoin, S., Emson, P., Goldstein, M. \& Hökfelt, T. (1995). The cholinergic innervation of the adrenal gland and its relation to enkephalin and nitric oxide synthase. Neuroreport, Vol.15 , No.6, (December 1995), pp. 2576-2580, ISSN 09594965.

Holgert, H., Dagerlind, A., \& Hökfelt, T. (1998). Immunohistochemical characterization of the peptidergic innervation of the rat adrenal gland. Hormone Metabolic Research, Vol.30 , No.6-7, (Julio 1998), pp. 315-322, ISSN 0018-5043.

$\mathrm{Hu}$, J., Zhang ,Z., Shen, W. J. Azhar, S. (2010). Cellular cholesterol delivery, intracellular processing and utilization for biosynthesis of steroid hormones. Nutrition $\mathcal{E}$ metabolism (Lond). Vol. 7, (June 1), p. 47, ISSN 1743-7075.

Ishimaru, R. S., Leung, K., Hong L., \& LaPolt, P. S. (2001). Inhibitory effects of nitric oxide on estrogen production and cAMP levels in rat granulosa cell cultures. Journal of Endocrinology, Vol. 168, No.8, (February 2001), pp. 249-255, ISSN 0022-0795.

Jana, B., Dzienis, A., Wojtkiewicz, J., Kaczmarek, M., \& Majewski, M. (2007). Surgical denervation of porcine ovaries during the middle luteal phase of the oestrous cycle changes their morphology and steroidogenic activity. Acta Veterinaria Hungarica, Vol.55, No.5, (March 2007), pp. 107-122, ISSN 1588-2705.

Kagerer, S. M. \& Jöhren O. (2010). Interactions of orexins/hypocretins with adrenocortical functions. Acta Physiologica (Oxford, England), Vol.198 , No.3, (March 2010), pp. 361371, ISSN 1748-1716.

Karamouti, M, Kollia, P, Kallitsaris, A, Vamvakopoulos, N, Kollios, G, \& Messinis, IE. (2009). Modulating effect of leptin on basal and follicle stimulating hormone stimulated 
steroidogenesis in cultured human lutein granulosa cells. Journal of Endocrinological Investigation, Vol.32, No.5, (May 2009), pp. 415-419, ISSN 0022-0795.

Kawakami, M., Kubo K., Uemura, T. \& Nagase, M.(1979). Evidence for the existence of extra-hypophyseal neural mechanisms controlling ovarian steroid secretion. Journal of Steroid Biochemistry, Vol.11, No.1C, (July 1979), pp. 1001-1005, ISSN 0022-4731.

Kawakami, M., Kubo, K., Uemura, T., Nagase, M. \&, Hayashy, R.(1981). Involvement of ovarian innervation on steroid secretion. Endocrinology, Vol. 109, No.1, (July 1981), pp. 136-145, ISSN 1945-7170.

Klein, C. M. \& Burden, H. W. (1988). Anatomical localization of afferent and postganglionic sympathetic neurons innervating the rat ovary. Neuroscience Letters, Vol.85 , No.2, (February 1988), pp. 217-222, ISSN 0304-3940.

Kondo, H. (1985). Immunohistochemical analysis of the localizationof neuropeptides in the adrenal gland. Archivum Histologicum Japonicum, Vol. 48, No.5, (December 1985), pp. 453-481, ISSN 0004-0681.

Kostic, T. S., Stojkov, N. J., Bjelic, M. M., Mihajlovic, A. I., Janjic, M. M. \& Andric, S. A. (2011) Pharmacological doses of testosterone up-regulated androgen receptor (AR) and 3beta-hydroxysteroid dehydrogenase/delta-5-delta-4 isomerase (3\{beta\}HSD) and impaired Leydig cells steroidogenesis in adult rat. Toxicological Sciences, Vol.120, No.2, (April 2011), pp. 397-407, ISSN 10966080.

Kuramoto, H., Kondo, H., \& Fujita, T. (1987). Calcitonin gene-related peptide (CGRP)-like immunoreactivity in scattered chromaffin cells and nerve fibers in the adrenal gland of rats. Cell $\mathcal{E}$ Tissue Research, Vol. 247, No.2, (February 1987), pp. 309-315, ISSN 1432-0878.

Lee, J., Park, H.J., Choi, H.S., Kwon, H.B., Arimura, A., Lee, B,J,, Choi, W.S. \& Chun S.Y. (1999). Gonadotropin stimulation of pituitary adenylate cyclase-activating polypeptide (PACAP) messenger ribonucleic acid in the rat ovary and the role of PACAP as a follicle survival factor. Endocrinology. Vol. 140, No. 2 (February 1999), pp.818-826, ISSN 0013-7227.

Lin, K.C., Okamura, H. \& Mori T. (1997). Inhibition of human chorionic gonadotropininduced ovulation and steroidogenesis by short-term hyperprolactinemia in female rabbits. Endocrinologia Japonica, Vol. 34, No. 5, (October 1997), pp. 675-683, ISNN0013-7219

Luo, W., Gumen, A., Haughian, J. M. \& Wiltbank, M. . (2011). The role of luteinizing hormone in regulating gene expression during selection of a dominant follicle in cattle. Biology of Reproduction, Vol.84, No.2, (February 2011), pp. 369-78, ISSN 15297268 .

Makarevich, A.V., Sirotkin, A.V., \& Genieser, H.G. (2004). Action of protein kinase A regulators on secretory activity of porcine granulosa cells in vitro. Animal Reproduction Science, Vol.81, No.1-2, (March 2004), pp. 125-36, ISSN 0378-4320.

Malendowicz, L. K. Rucinsk, M., Belloni, A.S, Ziolkowska, A. \& Nussdorfer, G. G. (2007). Leptin and the regulation of the hypothalamic-pituitary-adrenal axis. International Reviews of Cytology, Vol. 263, (August 2007), pp. 63-102, ISSN 0074-7696.

Malendowicz, L.K., Tortorella, C., \& Nussdorfer, G. G. (1999). Orexins stimulate corticosterone secretion of rat adrenocortical cells, through the activation of the adenylate cyclase-dependent signaling cascade. The Journal of Steroid Biochemistry $\mathcal{E}$ Molecular Biology, Vol. 70, No.4-6, (Sep-October 1999), pp. 185-188, ISSN 0960-0760. 
Malendowicz, L. K., Neri, G., Markowska, A., Hochol, A., Nussdorfer, G. G. \& Majchrzak, M. (2003). Effects of leptin and leptin fragments on steroid secretion of freshly dispersed rat adrenocortical cells. The Journal of Steroid Biochemistry \& Molecular Biology, Vol. 87, No. 4-5, (December 2003), pp. 265-2688, ISSN 0960-0760.

Manna, P.R., Kero J., Tena-Sempere, M., Pakarinen, P., Stocco, D.M., \& Huhtaniemi, I.T. (2001). Assessment of mechanisms of thyroid hormone action in mouse Leydig cells: regulation of the steroidogenic acute regulatory protein, steroidogenesis, and luteinizing hormone receptor function. Endocrinology, Vol. 142, No.1, (January 2001), pp. 319-31, ISSN 1945-7170.

Manna, P.R., Tena-Sempere, M., Huhtaniemi, I.T. (1999). Molecular mechanisms of thyroid hormone-stimulated steroidogenesis: involvement of steroidogenic acute regulatory (StAR) protein. Journal of Biological Chemistry. Vol. 274, No.,9 (February 26), pp. 5909-5918, ISSN 1083-351X.

Maran, R.R., Arunakaran, J. \& Aruldhas, M.M. (2000). T3 directly stimulates basal and modulates $\mathrm{LH}$ induced testosterone and oestradiol production by rat Leydig cells in vitro. Endocrinologia Japonica. Vol. 47, No. 4 (August 2000), pp.417-428, ISNN0013-7219.

Markowska, A., Neri, G., Hochol,A., Nowak, M., Nussdorfer ,G.G., \& Malendowicz, L.K. (2004). Effects of leptin and leptin fragments on steroid secretion and proliferative activity of regenerating rat adrenal cortex. International Journal of Molecular Medicine Vol. 13, No.1, (January 2004), pp. 139-141, ISSN 1107-3756.

Mavridou, S., Venihaki, M., Rassouli, O., Tsatsani,s C., \& Kardassis D. (2010). Feedback inhibition of human scavenger receptor class B type I gene expression by glucocorticoid in adrenal and ovarian cells. Endocrinology, Vol. 151, No.7, (July 2010), pp. 3214-24, ISSN 1945-7170.

Mayerhofer, A., Dissen, G. A., Costa, M. E., \& Ojeda, S. R. (1997). A role for neurotransmitters in early follicular development: induction of functional folliclestimulating hormone receptors in newly formed follicles of the rat ovary. Endocrinology, Vol.138, No.9, (August 1997), pp. 3320-3329, ISSN 1945-7170.

Mazzocchi, G., Rebuffat, P., Meneghelli, V., Malendowicz, L.K., Tortorella, C., Gottard,o G., \& Nussdorfer, G. G. (1999). Gastric inhibitory polypeptide stimulates glucocorticoid secretion in rats, acting through specific receptors coupled with the adenylate cyclase-dependent signaling pathway. Peptides, Vol.20 , (1999), pp. 589594 , ISSN 0196-9781.

Mészárosová, M., Sirotkin, A.V., Grossmann, R., Darlak, K., \& Valenzuela, F. (2008). The effect of obestatin on porcine ovarian granulosa cells. Animal Reproduction Science, Vol. 108, No. 1-2, (October 2008), pp. 196-207, ISSN 0378-4320.

Miszkiel, G., \& Kotwica, J. (2001). Mechanism of action of noradrenaline on secretion of progesterone and oxytocin by the bovine corpus luteum in vitro. Acta Veterinaria Hungarica, Vol.49, No.1, pp. 39-51, ISSN 1588-2705.

Morales-Ledesma, L., Ramírez, D.A., Vieyra, E., Trujillo, A., Chavira, R., Cárdenas, M. \& Domínguez R. (2011). Effects of acute unilateral ovariectomy to pre-pubertal rats on steroid hormones secretion and compensatory ovarian responses. Reproductive Biology and Endocrinology. Vol. 9, (March 30 2011), p. 41, ISSN 1477-7827.

Morán, C., Franco, A., Morán, J,L, Handal, A, Morales, L, \& Domínguez R. (2005). Neural activity between ovaries and the prevertebral celiac-superior mesenteric ganglia 
varies during the estrous cycle of the rat. Endocrine Vol. 26, No. 2 (March 2005), pp. 147-156, ISSN: 1559-0100.

Nimz, M., Spitschak, M., Fürbass, R., \& Vanselow, J. (2010). The pre-ovulatory luteinizing hormone surge is followed by down-regulation of CYP19A1, HSD3B1, and CYP17A1 and chromatin condensation of the corresponding promoters in bovine follicles. Molecular Reproduction and Development, Vol.77, No.12, (December 2010), pp. 1040-1048, ISSN 1098-2795.

Niswender, G.D. (2002). Molecular control of luteal secretion of progesterone. Reproduction. Vol. 123, No. 3 (March 2002), pp. 333-339, ISSN 1741-7899.

Nussdorfer, G.G., Bahçelioglu ,M., Neri, G. \& Malendowicz, L.K. (2000). Secretin, glucagon, gastric inhibitory polypeptide, parathyroid hormone, and related peptides in the regulation of the hypothalamus- pituitary-adrenal axis. Peptides, Vol. 21, No.12, (February 2000), pp. 309-324, ISSN 0196-9781.

Ramírez, D. A., Vieyra, E., Morales, L. \& Dominguez, R. (2008). The acute effects of unilateral ovariectomy to prepubertal rats on gonadotropin and hormone ovarian secretion are asymmetric. Program No. 81.3 Washington, DC: Society for Neuroscience; 2008, Online.

Renshaw, D., Thomson, L.M., Carroll, M., Kapas. S. \& Hinson J.P. (2000). Actions of neuropeptide $\mathrm{Y}$ on the rat adrenal cortex. Endocrinology. Vol. 141, No. 1 (January 2000), pp. 169-173, ISSN 1945-7170.

Rey-Ares, V., Lazarov, N., Berg, D., Berg, U., Kunz, L. \& Mayerhofer, A. (2007). Dopamine receptor repertoire of human granulosa cells. Reproductive Biology \& Endocrinology. Vol.5, (October 25), pp. 40, ISSN 1477-7827.

Ricci, A. G., Di Yorio, M. P. \& Faletti, A. G. (2006). Inhibitory effect of leptin on the rat ovary during the ovulatory process. Reproduction, Vol. 132, No. 5, (November 2006), pp. 771-780, ISSN 1741-7899

Ronti, T., Lupattelli. G. \& Mannarino, E. (2006). The endocrine function of adipose tissue: an update. Clinical Endocrinology (Oxf). 2006 Vol. 64, No.4, (April), pp.355-365. ISSN 0300-0664.

Sirotkin, A.V., Makarevich, A.V. \& Grosmann R. (2011). Protein kinases and ovarian functions. Journal of Cellular Physiology. Vol. 226, No. 1(September), pp. 37-45, INSS 1097-4652.

Sirotkin, A.V. \& Grossmann, R. (2007a). The role of ghrelin and some intracellular mechanisms in controlling the secretory activity of chicken ovarian cells. Comparative Biochemistry and Physiology. Part A. Molecular \& Integrative Physiology, Vol.147, No.1, (May 2007), pp. 239-246, ISSN 1531-4332.

Sirotkin, A.V., \& Grossmann, R. (2007b). Leptin directly controls proliferation, apoptosis and secretory activity of cultured chicken ovarian cells. Comparative Biochemistry and Physiology. Part A. Molecular \& Integrative Physiology. Vol. 148, No.2, (October 2007), pp.422-429, ISSN 1531-4332.

Sirotkin, A.V, Makarevich A.V, \& Grosmann ,R. (2011). Protein kinases and ovarian functions. Journal of Cellular and Comparative Physiology, Vol.226, No.1, (January 2011), pp. 37-45, ISSN 0095-9898.

Spicer, L. J . \& Francisco, C. C. (1997). The adipose obese gene product, leptin: evidence of a direct inhibitory role in ovarian function. Endocrinology, Vol. 138, No.8, (August 1997), pp. 3374-3379, ISSN 1945-7170. 
Spiga, F, Liu, Y., Aguilera, G. \& Lightman, S.L. (2011). Temporal effect of adrenocorticotrophic hormone on adrenal glucocorticoid steroidogenesis: involvement of the transducer of regulated cyclic AMP-response element-binding protein activity. Journal of Neuroendocrinology, Vol. 23, No.2, (February 2001), pp. 136-142, ISSN 0028-3835.

Spinazzi, R., Andreis, P.G., Rossi, G.P. \& Nussdorfe,r G.G. (2006). Orexins in the regulation of the hypothalamic-pituitary-adrenal axis. Pharmacological Reviews, Vol.58 , No.1, ( March 2006), pp.46-57, ISSN 1521-0081.

Stocco, C. (2008). Aromatase expression in the ovary: hormonal and molecular regulation. Steroid, Vol.73 , No.5, (May 2008), pp.473-478 , ISSN 0039-128x.

Strauss, J. R- III \& Hsueh, A. J. W. (2000). Ovarian hormone synthesis. In: Endocrinology Fourth Edition edited by LJ De Groot and JL Jameson vol 3, Chap. 148, pp 2043-2052. WB Saunders Co. ISBN 0-7216-7840-8 (set). Philadelphia, Pennsylvania

Sugawara, T., Kiriakidou, M., McAllister, J. M., Holt, J. A., Arakane, F. \& Strauss, J. F. 3rd. (1997). Regulation of expression of the steroidogenic acute regulatory protein (StAR) gene: a central role for steroidogenic factor 1. Steroids, Vol.62, No.1, (January 1997), pp.5-9, ISSN 0039-128x.

Szalay, K. S, Orsó, E., Jurányi, Z., Vinson, G. . \& Vizi, E. S. (1998). Local non-synaptic modulation of aldosterone production by catecholamines and ATP in rat: implications for a direct neuronal fine tuning. Hormone Metabolic Research, Vol.30, No.6-7, (June-July), pp. 323-328, ISSN 0018-5043.

Tortorella, C., Neri, G. \& Nussdorfer, G.G. (2007). Galanin in the regulation of the hypothalamic-pituitary-adrenal axis (Review). International Journal of Molecular Medicine, Vol.19 , No.4, (April 2007), pp. 639-647, ISSN 1107-3756.

Tóth I.E., Wiesel O., Boldogkoi, Z., Bálint, K., Tapaszti, Z. \& Gerendai, I. (2007). Predominance of supraspinal innervation of the left ovary. Microscopic Research Technique. Vol. 70, No.8, (August 2007), pp.710-718, ISSN 1097-0029.

Tóth, I.E., Wiesel, O., Boldogkoi, Z., Bálint, K., Tapaszti, Z. \& Gerendai I. (2007). Predominance of supraspinal innervation of the left ovary. Microscopy Research Technique. Vol. 70, No. 8 (August 2007), pp.710-718 ISSN 1097-0029.

Tropea, A., Lanzone, A., Tiberi,F., Romani, F., Catino, S. \& Apa, R. (2010). Estrogens and androgens affect human luteal cell function. Fertility $\mathcal{E}$ Sterility, Vol. 94, No. 6, (November 2010), pp. 2257-2263, ISSN 0015-0282.

Trujillo, A., Morales, L., Dominguez, R. \& Vindrola, O. (2001). Effects of sensorial denervation on the ovarian functions in the adult rat. Program No. 734.14 Neuroscience Meeting Planner. San Diego, Ca; 2001.

Trujillo, A., Morales, L., Vargas, X., Alba, L. \& Domínguez R. (2004). Effects of capsaicin treatment on the regulation of ovarian compensatory hypertrophy and compensatory ovulation. Endocrine, Vol. 25, No. 2, (November 2004), pp. 155-162, ISSN: 1559-0100.

Uchida, S., Kagitani F., Hotta, H., Hanada, T. \& Aikawa, Y. (2005). Cutaneous mechanical stimulation regulates ovarian blood flow via activation of spinal and supraspinal reflex pathways in anesthetized rats. The Japanese journal of Physiology, Vol. 55, No.5, (October 2005), pp.265-277, ISSN 1881-1396. 
Ulrich-Lai, Y. M. \& Engeland, W. C. (2000). Hyperinnervation during adrenal regeneration influences the rate of functional recovery. Neuroendocrinology, Vol.71, No.2, (February 2000), pp.107-123, ISSN 0028-3835.

Ulrich-Lai, Y. M., Arnhold, M. M. \& Engeland, W. C. (2006). Adrenal splanchnic innervation contributes to the diurnal rhythm of plasma corticosterone in rats by modulating adrenal sensitivity to ACTH. American Journal of Physiology Regulatory, Integrative and Comparative Physiology, Vol.290, No.4, (April2006), pp. R1128-1135, ISSN 15221490.

Wang, H., Eriksson, H. \& Sahlin, L. (2000) Estrogen receptors a and $\beta$ in the female reproductive tract of the rat during the estrous cycle. Biology of Reproduction, Vol. 63, No.5, (November 1, 2000), pp. 1331-1340, ISSN 1529-7268.

Whitworth, E. J, Kosti, O., Renshaw, D., \& Hinson, J.P. (2003). Adrenal neuropeptides: regulation and interaction with $\mathrm{ACTH}$ and other adrenal regulators. Microscopy Research and Technique, Vol.61, No.3, (June 15), pp. 259-267, ISSN 1097-0029.

Wu, J.L., Wu, R.S., Yang, J.G., Huang, C.C., Chen, K.B., Fang, K.H. \& Tsai H. D. (2011). Effects of sleep deprivation on serum testosterone concentrations in the rat. Neuroscience Letters, Vol. 494, No.2, (April 25, 2011 ), pp. 124-129, ISSN 1872-7972.

Zachow, R.J. \& Magoffin, D. A. (1997). Direct intraovarian effects of leptin: impairment of the synergistic action of insulin-like growth factor-I on follicle-stimulating hormone-dependent estradiol-17 beta production by rat ovarian granulosa cells. Endocrinology, Vol. 138, No. 2, (February 1997), pp. 847-850, ISSN 0013-7227.

Zachow, R. J, Weitsman, S. R., \& Magoffin, D. A. (1999). Leptin impairs the synergistic stimulation by transforming growth factor-beta of follicle-stimulating hormonedependent aromatase activity and messenger ribonucleic acid expression in rat ovarian granulosa cells. Biology of Reproduction, Vol. 61, No. 4, (October 1999), pp. 1104-1109. ISSN: 0006-3363. 


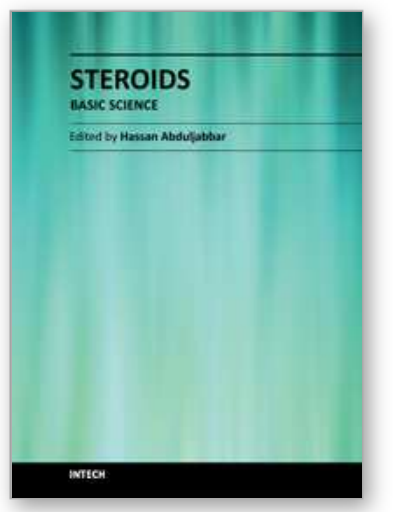

\author{
Steroids - Basic Science \\ Edited by Prof. Hassan Abduljabbar
}

ISBN 978-953-307-866-3

Hard cover, 234 pages

Publisher InTech

Published online 11, January, 2012

Published in print edition January, 2012

This book explains the basic science of steroids and is targeted towards professionals engaged in health services. It should be noted that medical science evolves rapidly and some information like the understanding of steroids and their therapeutic use may change with new concepts quickly. Steroids are either naturally occurring or synthetic fat-soluble organic compounds. They are found in plants, animals, and fungi. They mediate a very diverse set of biological responses. The most widespread steroid in the body is cholesterol, an essential component of cell membranes, and the starting point for the synthesis of other steroids. Since the science of steroids has an enormous scope, we decided to put the clinical aspects of steroids in a different book titled "Steroids-Clinical Aspects". The two books complete each other. We hope that the reader will gain valuable information from both books and enrich their knowledge about this fascinating topic.

\title{
How to reference
}

In order to correctly reference this scholarly work, feel free to copy and paste the following:

Roberto Domínguez, Angélica Flores and Sara E. Cruz-Morales (2012). Hormonal and Neural Mechanisms Regulating Hormone Steroids Secretion, Steroids - Basic Science, Prof. Hassan Abduljabbar (Ed.), ISBN: 978953-307-866-3, InTech, Available from: http://www.intechopen.com/books/steroids-basic-science/hormonaland-neural-mechanisms-regulating-hormone-steroids-secretion

\section{INTECH}

open science | open minds

\author{
InTech Europe \\ University Campus STeP Ri \\ Slavka Krautzeka 83/A \\ 51000 Rijeka, Croatia \\ Phone: +385 (51) 770447 \\ Fax: +385 (51) 686166 \\ www.intechopen.com
}

\author{
InTech China \\ Unit 405, Office Block, Hotel Equatorial Shanghai \\ No.65, Yan An Road (West), Shanghai, 200040, China \\ 中国上海市延安西路65号上海国际贵都大饭店办公楼405单元 \\ Phone: +86-21-62489820 \\ Fax: $+86-21-62489821$
}


(C) 2012 The Author(s). Licensee IntechOpen. This is an open access article distributed under the terms of the Creative Commons Attribution 3.0 License, which permits unrestricted use, distribution, and reproduction in any medium, provided the original work is properly cited. 